\title{
Article \\ Thermodynamic Rarity Assessment of Mobile Phone PCBs: A Physical Criticality Indicator in Times of Shortage
}

\author{
Jorge Torrubia *(D), Antonio Valero and Alicia Valero \\ Instituto CIRCE (Research Centre for Energy Resources and Consumption), Universidad de Zaragoza, \\ 50018 Zaragoza, Spain; valero@unizar.es (A.V.); aliciavd@unizar.es (A.V.) \\ * Correspondence: jtorrubia@unizar.es
}

check for updates

Citation: Torrubia, J.; Valero, A.; Valero, A. Thermodynamic Rarity Assessment of Mobile Phone PCBs: A Physical Criticality Indicator in Times of Shortage. Entropy 2022, 24, 100. https://doi.org/10.3390/e24010100 Academic Editors: Jean-Noël Jaubert and Attila R. Imre

Received: 25 November 2021

Accepted: 4 January 2022

Published: 8 January 2022

Publisher's Note: MDPI stays neutral with regard to jurisdictional claims in published maps and institutional affiliations.

Copyright: (C) 2022 by the authors. Licensee MDPI, Basel, Switzerland. This article is an open access article distributed under the terms and conditions of the Creative Commons Attribution (CC BY) license (https:// creativecommons.org/licenses/by/ $4.0 /)$.

\begin{abstract}
Rising prices in energy, raw materials, and shortages of critical raw materials (CRMs) for renewable energies or electric vehicles are jeopardizing the transition to a low-carbon economy. Therefore, managing scarce resources must be a priority for governments. To that end, appropriate indicators that can identify the criticality of raw materials and products is key. Thermodynamic rarity (TR) is an exergy-based indicator that measures the scarcity of elements in the earth's crust and the energy intensity to extract and refine them. This paper uses TR to study 70 Mobile Phone (MP) Printed Circuit Boards (PCBs) samples. Results show that an average MP PCB has a TR of $88 \mathrm{MJ}$ per unit, indicating their intensive use of valuable materials. Every year the embedded TR increase by 36,250 GWh worldwide -similar to the electricity consumed by Denmark in 2019- due to annual production of MP. Pd, Ta and Au embedded in MP PCBs worldwide between 2007 and 2021 contribute to $90 \%$ of the overall TR, which account for 75, 600 and 250 tones, respectively, and increasing by $11 \%$ annually. This, coupled with the short lifespan of MP, makes PCBs an important potential source of secondary resources.
\end{abstract}

Keywords: thermodynamic rarity; resource scarcity; critical raw materials; printed circuit boards; mobile phones

\section{Introduction}

The whole world is experiencing soaring energy and raw material costs. Europe is particularly vulnerable to this situation which must import a large part of the raw material domestically consumed by industry and households [1]. Rising energy prices -driven by fossil fuel prices [2]- (electricity [3-6], natural gas [7] and gasoline and diesel [8]), food [9,10] (fertilizers [11]) and livestock feed [12]), shipping [13,14] and even the lack of microchips for factories [15,16], are examples of this. These supply issues occur when the transformation to a low-carbon economy driven by renewables, electric vehicles, and digitization is beginning to accelerate. This situation could jeopardize the transition since a low-carbon economy requires a large quantity and variety of raw materials. For example, to produce one gigawatt (GW) of electrical power equivalent to that which a natural gas-fired power plant could supply would imply the use of approximately 160,000 tons of steel, 2000 of copper, 780 of aluminum, 110 of nickel, 85 of neodymium and 7 of dysprosium for its construction [17]. These are not negligible amounts if it is estimated that in the future, the power provided by wind turbines in 2050 could be around 2200 GW [18].

Another example is that demand for some minerals for batteries could increase dramatically by 2040 -with respect to 2020-lithium 42 times, cobalt 21 times, nickel 19 or Rare Earth Elements (REE) 7, as the International Energy Agency (IEA) warns [19]. Thus, the use of scarce minerals -needed in a low-carbon economy-could pose a problem for future generations due to their eventual depletion and unavailability in the future [20]. Furthermore, these raw materials are mainly extracted from mines that need fossil fuels to operate. The IEA's World Energy Outlook 2021 indicates that oil and natural gas production could 
fall by $8-9 \%$ per year without new investments [2]. They have fallen from $\$ 779$ billion in 2014 to $\$ 328$ billion in 2020 [21], i.e., they have halved in 6 years. The combination of these factors could lead to bottlenecks of raw materials needed for decarbonization. Therefore, it is essential to strengthen raw material supply chains seeking alternative sources such as e-waste. According to Henckens 2021 [20], if the most stringent resource-saving measures were applied, it would be possible to extend the depletion periods of certain materials required for the energy transition by four times, even if the global service level increases.

This paper examines the raw materials embedded in printed circuit boards (PCBs) in Mobile Phones (MP) as a potential source of secondary resources. These devices have become, in recent years, irreplaceable devices for communication worldwide. The rapid growth in their sales evidences this. MP sales began to proliferate from 2009, reaching approximately constant annual sales of 1.5 billion phones between 2016 and 2020. Resulting in cumulative sales between 2007 and 2020 of almost 14 billion phones and almost doubling the world's population [22]. The large number of MP, coupled with their short lifespan of around four years [23], contributes to the continuous increase of e-waste, which according to some projections, reach 52.2 million tons in 2021 [24] with an annual growth of 3-5\%, a rate three times faster than the increase of municipal solid waste [25]. The most polluting part of a MP is the Printed Circuit Board (PCB) it contains. PCBs account for more than $70 \%$ of the carbon footprint of production [26]. In addition, it is the most heterogeneous and complicated fraction [24] as it is composed of a high diversity of elements -more than 40- and elemental concentrations [27]. Some of these elements -such as Pd, Ga or Ta- are scarce in nature [28] or a few countries control their production. Such is the case of Rare Earths Elements (REE), mainly controlled by China.

This issue has been studied by the European Commission (EC), which has been drawing up a list of Critical Raw Materials (CRMs) for the EU every three years since 2011 [29]. The EC criteria point to the economic importance for the EU economy and the supply risk of raw materials to assess criticality [28]. Such criteria are mainly based on geopolitical and economic aspects that are variable over time. For example, Si has soared 300\% in less than two months [30], the volatility of Pd has been evidenced by the International Energy Agency [19], the price of $\mathrm{Cu}$ has increased 300\% in 15 years [31] or REE prices increased 10-fold between 2009 and 2011 and then fell [32]. Moreover, the EC list has not stopped growing, the 2014 list contained 20 CRMs, the 2017 list 26 and the 2020 list 30 [33]. In addition, the list could expand in the future due to these price trends-characteristic in times of shortage-and the growing demand for metals needed for the energy transition [19].

In addition to economic and geopolitical factors, the criticality of an element is determined by its geological scarcity, as the first link in the supply chain of most CRM is mining, which will be one of the decisive factors for the success of renewable transition [19]. As mines become depleted and their ore grade decreases, the energy costs to extract the metal increase exponentially $[34,35]$. In the limit, a complete exhaustion of all mines would imply that the planet's mineral wealth would be dispersed, reaching the maximum level of entropy. This state of the planet has been called Thanatia by Valero and Valero [36]. Using this reference, Thermodynamic Rarity (TR) is presented as an exergy-based indicator capable of measuring the thermodynamic criticality of raw materials based on their geological scarcity and the energy intensity required to extract, beneficiate, and refine commodities. Thus, TR is a long-term indicator decoupled from political and economic factors but constrained by mining technology and geological knowledge of the earth's crust. More information about this indicator and its applications can be found in the following references [37-40]. TR has been proposed previously as a criticality indicator. For example, Calvo et al., 2018 [28] proposed to add Mo, Te, li, Ta, and V to the list of the 2014 EC CRMs due to their geological scarcity measured by TR. The last three have been added to the 2020 list of these elements. In addition, this indicator has already been successfully used in the study of Electrical and Electronic Equipment [41] and vehicles. Vehicle papers concluded that although $\mathrm{Fe}, \mathrm{Al}$ and $\mathrm{Cu}$ contribute to more than $90 \%$ of the car by weight, they only account for $60 \%$ of 
the TR [42] and that many high TR elements end up downcycled as part of alloys or in landfills. Downcycled elements represent $4.5 \%$ of the vehicles, while in TR terms, it would be 27\% [43]. Currently, EC legislation for End of Life Vehicles requires the recovery of 95\% of the vehicle by weight. This can be met by recovering major metals, yet the minor ones become lost or downcycled, losing their functionality. Horta Arduin et al., 2020 [44] has also highlighted this problem in the case of display waste. They state that there is a contradiction between the EC criteria, which on the one hand is concerned with the criticality of CRMs through the publication of lists, but on the other hand, the WEEE recycling regulations focus on weight, causing many critical elements to be lost due to their low contribution in weight. This makes new indicators necessary to reinforce current regulations.

This paper is structured as follows. First, TR indicator is explained. Second, the sources used to calculate the composition of the MP PCBs, the assumptions for calculating the TR and the estimation of resources embedded worldwide are shown. Third, the results of the mass composition, TR and resources worldwide are presented. Finally, the main conclusions are discussed.

\section{Materials and Methods}

\subsection{Thermodynamic Rarity Indicator}

TR is an indicator, based on exergy, used to measure the thermodynamic criticality of raw materials, depending on their scarcity in the earth's crust and the energy intensity associated with mining, beneficiation, and refining processes. Exergy is a property of a system relative to an associated reference state. It is the maximum work a system can deliver as it interacts with another large, but real, system, namely, a reservoir. Such a reservoir attracts the system toward degradation or entropy creation. The reference state selected for the exergy assessment of minerals is a planet, called "Thanatia" (from Greek Thanatos, meaning "death") with the following characteristics [39]:

- Crust: there are no concentrated mineral deposits (the upper continental crust can be approximated to the average mineralogical composition of the current earth's crust), fossil fuels have been depleted, and fertile soils are entirely degraded.

- Hydrosphere: its composition can be approximated to seawater since freshwater constitutes about $2.5 \%$ of global water, of which the most important part is composed of glaciers and ice sheets $(68.7 \%)$ and groundwater $(30.1 \%)$.

- Atmosphere: $\mathrm{CO}_{2}$ concentration is comparable to the complete burning of all remaining fossil fuels.

This imaginary state of the planet does not need to be "reachable", but it is a baseline to assess the quality of any resource physically. It further allows us to objectively identify which resource is closer to depletion in the race to exhaustion. Any mineral resource with a concentration higher than that found in Thanatia has exergy, and therefore, its quality can be quantified in energy terms [39]. TR incorporates two aspects. The first is the embedded exergy cost $(\mathrm{kJ})$, i.e., the useful energy required to extract and process a given mineral from the cradle to the gate (i.e., until it becomes a raw material for the manufacturing industry). The second is, in fact, an avoided cost for having minerals concentrated in mines and not dispersed throughout the crust (i.e., it can be seen as a natural bonus). As mines become depleted, it becomes exponentially harder to obtain commodities (embedded costs increase), whereas the bonus reduces. This bonus is calculated as a hypothetical exergy cost required if the given mineral would be restored to its initial composition conditions and concentration in the original mines from an utterly dispersed state, i.e., its state in Thanatia. This is the exergy replacement cost (ERC) ( $\mathrm{kJ}$ ) and can be seen as a grave-tocradle-approach [36] or as a natural avoided exergy cost, i.e., as a natural bonus. Thus, the TR is presented as a physical indicator, stable over time, based on thermodynamic fundamentals. However, it is conditioned by mining technology, as it could reduce the exergy costs of mineral extraction and the knowledge of the earth's crust that would modify the composition established for Thanatia. Another advantage is that it allows classifying 
the elements in order of criticality since each element has a unique value, measured in exergy terms.

TR values $\left(R_{i}\right)$ of the analyzed elements, measured in $\frac{G J}{\operatorname{ton}_{i}}$ are shown in Table 1 [28]. Nevertheless, TR values could be higher than those used. As an example, Palacios et al. [45] obtained TR values 2 to 3 orders of magnitude higher than previous values for $\mathrm{Cu}$ and $\mathrm{Au}$, using metallurgical process simulation, more specifically the HSC Chemistry software.

Table 1. Embedded exergy, exergy replacement cost and thermodynamic rarity of the chemical elements that compose a mobile phone PCB. * Average between ores [28].

\begin{tabular}{|c|c|c|c|}
\hline Element (ore) & $\begin{array}{l}\text { Embedded Exergy } \\
\text { (GJ/ton) }\end{array}$ & $\begin{array}{c}\text { Exergy } \\
\text { Replacement Cost } \\
\text { (GJ/ton) }\end{array}$ & $\begin{array}{c}\text { Thermodynamic } \\
\text { Rarity } \\
\text { (GJ/ton) }\end{array}$ \\
\hline $\mathrm{Ag}$ & 1566 & 7371 & 8938 \\
\hline Al (Bauxite-Gibbsite) & 54 & 627 & 682 \\
\hline As (Arsenopyrite) & 28 & 400 & 427 \\
\hline $\mathrm{Au}$ & 110,057 & 553,250 & 663,308 \\
\hline $\mathrm{Ba}$ & 1 & 38 & 39 \\
\hline Be (Beryl) & 457 & 253 & 710 \\
\hline Bi (Bismuthinite) & 56 & 489 & 545 \\
\hline Cd (Greenockite) & 542 & 5898 & 6440 \\
\hline Ce (Monazite) & 523 & 97 & 620 \\
\hline Co (Linnaeite) & 138 & 10,872 & 11,010 \\
\hline Cr (Chromite) & 36 & 5 & 41 \\
\hline Cu (Chalcopyrite) & 57 & 292 & 349 \\
\hline Fe (Hematite) & 14 & 18 & 32 \\
\hline Ga (in Bauxite) & 610,000 & 144,828 & 754,828 \\
\hline Gd (Monazite) & 3607 & 478 & 4085 \\
\hline Ge (in Zinc) & 498 & 23,750 & 24,248 \\
\hline $\mathrm{Hf}$ & 11,183 & 21,814 & 32,997 \\
\hline Hg (Cinnabar) & 409 & 28,298 & 28,707 \\
\hline In (in Zinc) & 3320 & 360,598 & 363,917 \\
\hline K (Sylvite) & 2 & 665 & 667 \\
\hline La (Monazite) & 297 & 39 & 336 \\
\hline Li (Spodumene) & 433 & 546 & 979 \\
\hline Mg (from Ocean) & 10 & 26 & 36 \\
\hline Mn (Pyrolusite) & 58 & 16 & 74 \\
\hline Mo (Molibdenite) & 148 & 908 & 1056 \\
\hline $\mathrm{Na}$ (Halite) & 43 & 44 & 87 \\
\hline Nd (Monazite) & 592 & 78 & 670 \\
\hline Ni (Pentlandite and Garnierite) * & 265 & 465 & 729 \\
\hline $\mathrm{P}$ (Ápatite) & 5 & 0 & 5 \\
\hline $\mathrm{Pb}$ (Galena) & 4 & 37 & 41 \\
\hline $\mathrm{Pd}$ & 583,333 & $8,983,377$ & $9,566,710$ \\
\hline Pr (Monazite) & 296 & 577 & 873 \\
\hline $\mathrm{Pt}$ & 291,667 & $4,491,690$ & $4,783,357$ \\
\hline Sb (Stibnite) & 13 & 474 & 487 \\
\hline Si (Quartz) & 77 & 1 & 77 \\
\hline Sn (Cassiterite) & 27 & 426 & 453 \\
\hline Sr & 72 & 4 & 78 \\
\hline Ta (Tantalite) & 3091 & 482,828 & 485,919 \\
\hline $\mathrm{Ti}$ (Ilmenite and Rutile) * & 196 & 7 & 203 \\
\hline W (Scheelite) & 594 & 7430 & 8024 \\
\hline Y (Monazite) & 1198 & 159 & 1357 \\
\hline Zn (Sphalerite) & 42 & 155 & 197 \\
\hline Zr (Zircon) & 1372 & 654 & 2026 \\
\hline
\end{tabular}




\subsection{Mobile Phone PCB Data: Composition, Thermodynamic Rarity Calculation and Resources Embedded Worldwide}

PCB composition has been obtained by reviewing the literature. A total of 70 samples were taken from Chancerel et al., 2009 [46] (3 samples), Kasper et al., 2011 [47] (3 samples), Oguchi et al., 2011 [48] (2 samples), Yamane et al., 2011 [49] (1 sample), Silvas et al., 2015 [50] (1 sample), Ueberschaar et al., 2017 [51] (1 sample), Ueberschaar et al., 2017 [52] (2 samples), Arshadi et al., 2018 [53] (1 sample), Holgersson et al., 2018 [54] (10 samples), Li et al., 2018 [24] (1 sample), Gu et al., 2019 [27] (12 samples), Korf et al., 2019 [55] (14 samples), Sahan et al., 2019 [25] (19 samples). All data have been transformed to mg element per $\mathrm{kg}$ PCB and the complete results have been compiled in Appendix A. Analyzed MP were manufactured between 2004 and 2014. PCBs were subjected to mechanical processing (shredding, comminution or milling), and then the resulting powder was analyzed using different techniques such as ICP-AES, ICP-OES, ICP-MS o XRF.

The TR of a mobile phone (MP) PCB has been calculated through Equation (1). First, the TR of a $\mathrm{kg}$ of PCB is calculated (in parentheses). To do this, the product of the TR of an element $\left(R_{i}\right)$ by its concentration in the PCB is done and then the units of $\mathrm{kg}$ of PCB are transformed into units of MP.

$$
R_{P C B(\text { unit })}=\left(\sum_{i=1}^{n} R_{i} \cdot \frac{m g_{i}}{k g_{P C B}} \cdot \frac{1}{1 e 9}\right) \cdot \frac{k g_{P C B}}{k g_{M P}} \cdot \frac{k g_{M P}}{\text { Unit }_{M P}}
$$

Therefore, it is necessary to know its average weight and the percentage of PCBs it contains in relation to its weight. In this paper, as indicated in Equation (1), an average phone weight of $100 \mathrm{~g}$ and a PCB percentage by weight of $20 \%$ have been used to obtain conservative results. Table 2 shows the percentage of PCBs in phones according to different references. Equation (1) is also used to calculate the contribution of each element to the total TR to analyze the thermodynamic criticality of each element.

Table 2. Percentage by weight of PCB in a Mobile Phone.

\begin{tabular}{cccccccc}
\hline Source & {$[24]$} & {$[46]$} & {$[54]$} & {$[48]$} & {$[51]$} & {$[56]$} & {$[57]$} \\
\hline Minimum & $20 \%$ & $22 \%$ & $21 \%$ & $12.6 \%$ & $29.5 \%$ & $21 \%$ & $21.1 \%$ \\
Maximum & $30 \%$ & & & $30.3 \%$ & & & \\
\hline
\end{tabular}

To estimate the mass of elements embedded in MP PCBs worldwide, the annual sales of 2020 -around 1.5 billion- and the cumulative sales between 2007 and 2021 -around 14.8 billion units- are taken [22].

Finally, the ratio between the amount of elements embedded in MP PCBs worldwide and the annual extraction of the elements is calculated. For this purpose, the quantity of each element is divided by its extraction. Thus, two percentages are obtained depending on the number of MP considered. On the one hand, the cumulative quantity is considered, i.e., 14.8 billion units between 2007 and 2021; and, on the other hand, the annual sales are considered, i.e., 1.5 billion units. Thus, the first percentage represents the annual production that could be provided if that element were recovered from all the accumulated PCBs. In addition, the second percentage of annual production could be covered with the PCBs of one year. In other words, it would be approximately the percentage of the annual production that is used to produce MP PCBs. The extraction data for the elements were obtained from the U.S. Geological Survey 2021 commodity summaries [58]. In 2020, 210 tons of $\mathrm{Pd}, 1700$ tons of $\mathrm{Ta}, 3200$ tons of $\mathrm{Au}, 300$ tons of $\mathrm{Ga}, 20,000,000$ tons of $\mathrm{Cu}$, 170 tons of Pt and 900 tons of In were mined.

\section{Results}

\subsection{Composition and Thermodynamic Rarity of Mobile Phone PCBs}

The 70 MP PCBs samples reviewed are composed of 55 different chemical elements, of which 31 are considered as CRMs by the EC (Figure 1). Although the EC list contains 
30 commodities, some of them are groups of elements such as light REE or platinum group metals (PGM), so the number obtained is greater than 30 . Taking this into account, 25 elements in the MP PCB are considered critical by the EC. Nevertheless, the contribution by weight of these elements to the total PCBs is very different. Figure $2 a, b$ shows the results of the mass contribution of each element. As can be seen, more than $90 \%$ of the weight of PCBs is made up of 8 elements: $\mathrm{Cu}, \mathrm{Si}, \mathrm{Fe}, \mathrm{Br}, \mathrm{Sn}, \mathrm{Ni}, \mathrm{Al}$ and $\mathrm{Zn}$, being two CRMs according to the EC: Si and Al. Using the CE criterion, the remaining 47 elements constitute $10 \%$ of the overall weight, concentrating up to 23 CRMs. Therefore, most of the critical elements are characterized by low mass concentrations.

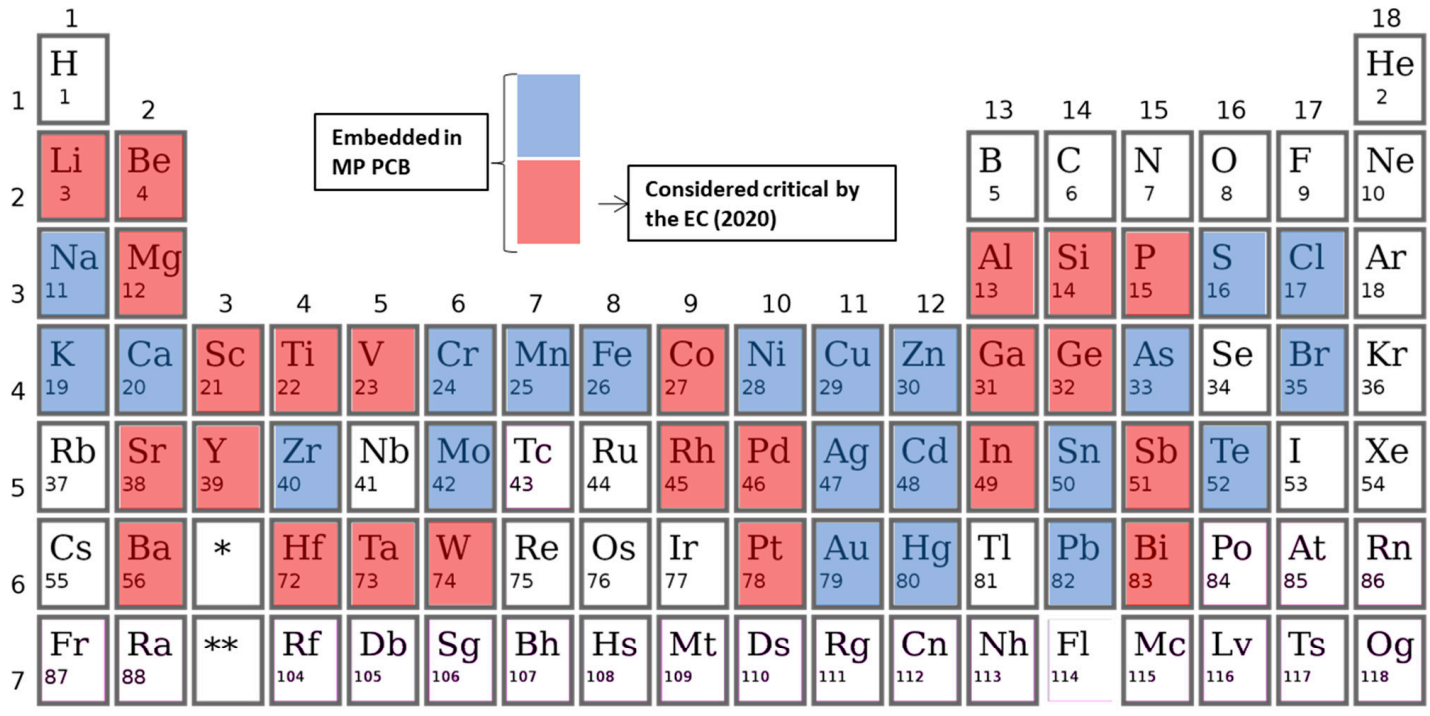

\begin{tabular}{|c|c|c|c|c|c|c|c|c|c|c|c|c|c|c|c|}
\hline * Ianthanoids & $\begin{array}{l}\mathrm{La} \\
57\end{array}$ & $\begin{array}{c}\mathrm{Ce} \\
58\end{array}$ & $\underset{59}{\mathrm{Pr}}$ & $\underset{60}{\mathrm{Nd}}$ & $\begin{array}{l}\mathrm{Pm} \\
61\end{array}$ & $\underset{62}{\mathrm{Sm}}$ & ${ }_{63}^{\mathrm{Eu}}$ & $\underset{64}{\mathrm{Gd}}$ & $\begin{array}{l}\mathrm{Tb} \\
65\end{array}$ & $\begin{array}{l}\text { Dy } \\
66\end{array}$ & $\begin{array}{l}\mathrm{Ho} \\
67\end{array}$ & $\begin{array}{l}\text { Er } \\
68\end{array}$ & $\mathrm{Tm}_{69}^{\mathrm{Tm}}$ & $\begin{array}{l}\text { Yb } \\
70\end{array}$ & $\underset{71}{\mathrm{Lu}}$ \\
\hline actinoids & $\begin{array}{l}\text { Ac } \\
89\end{array}$ & Th & $\underset{91}{\mathrm{~Pa}}$ & $\underset{92}{\mathrm{U}}$ & $\underset{93}{\mathrm{~Np}}$ & $\underset{94}{\mathrm{Pu}}$ & $\begin{array}{l}\text { Am } \\
95\end{array}$ & $\begin{array}{l}\mathrm{Cm} \\
96\end{array}$ & $\begin{array}{l}\text { Bk } \\
97\end{array}$ & $\begin{array}{l}\text { Cf } \\
98\end{array}$ & $\begin{array}{l}\text { Es } \\
99\end{array}$ & $\underset{100}{\mathrm{Fm}}$ & $\underset{101}{\mathrm{Md}}$ & $\underset{102}{\text { No }}$ & $\underset{103}{\mathrm{Lr}}$ \\
\hline
\end{tabular}

Figure 1. Periodic table showing the elements embedded in Mobile Phone PCBs. Elements considered critical by EC are highlighted in red.

To measure criticality, this paper uses the TR indicator. Thus, Figure $2 \mathrm{c}$ shows the results of the TR contribution of each element in kJ per unit of MP and Figure $2 \mathrm{~d}$ the results in percentage, according to the data and assumptions outlined in Section 2.2. If the TR of an element is unknown, it has been counted as 0 , as for Te or $\mathrm{Br}$ (see Table 1). Taking TR as a criterion, the results are radically different. There are now 3 elements that contribute to almost $90 \%$ of the TR: Pd, Ta and $\mathrm{Au}, 4$ others that account for $8 \%: \mathrm{Ga}, \mathrm{Cu}, \mathrm{Pt}$, and $\mathrm{In}$, and remaining 48 for only $2 \%$. Thus, seven elements account for $98 \%$ of the TR, being all of them CRMs according to the EC except $\mathrm{Au}$ and $\mathrm{Cu}$-the most abundant in PCBs-.

Summing the contribution of each element as shown in Equation (1), the results indicate that the TR of a PCB is $88 \mathrm{MJ}$ per MP unit. This result does not include other parts of the MP, such as the display, camera, or battery, so the TR of the complete MP is higher than obtained. Considering that between 2016 and 2020 mobile sales stagnate at around 1.5 billion mobiles per year (Figure $3 \mathrm{~b}$ ), the TR embedded in MP PCBs worldwide would increase by $1.305 \cdot 10^{11} \mathrm{MJ}$ o $36,250 \mathrm{GWh}$ per year, an amount comparable to the electricity consumed by Denmark in 2019 [59]. 


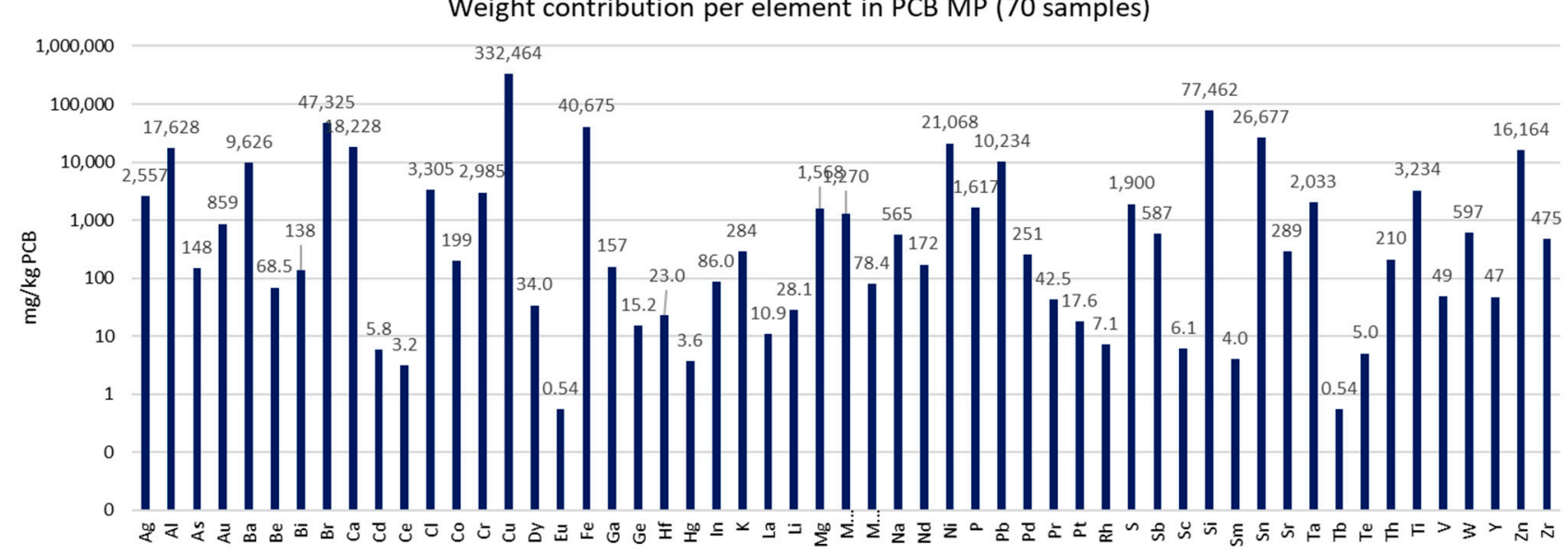

(a)

Thermodynamic Rarity per element in PCB MP (70 samples)

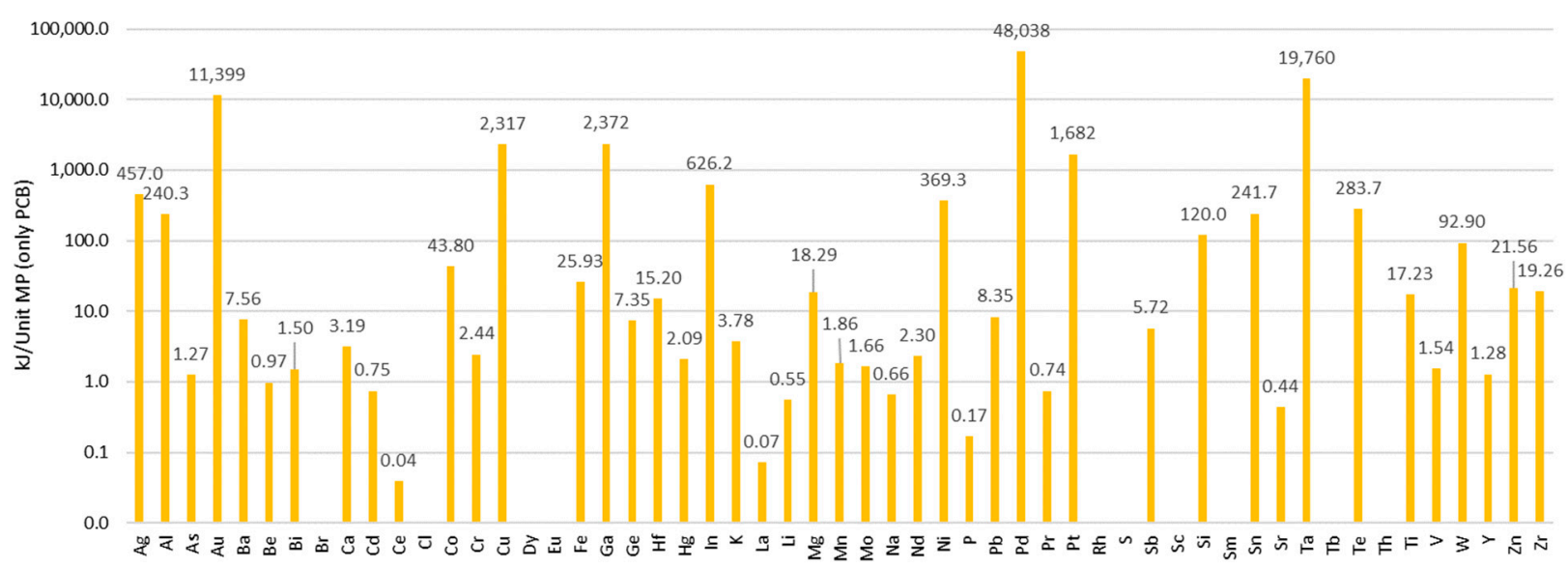

(c)
PCB MB composition (wt.\%)

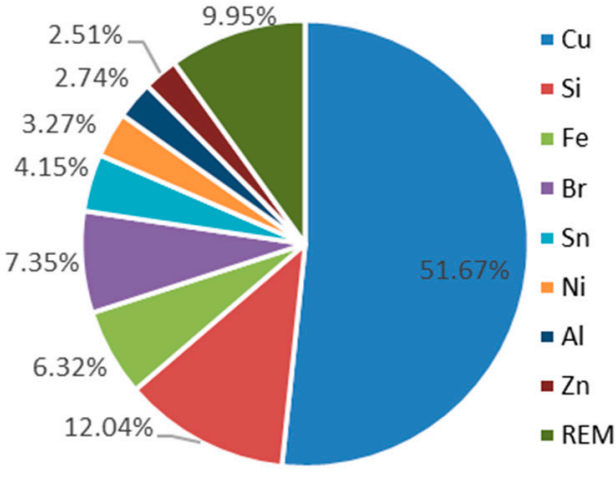

(b)

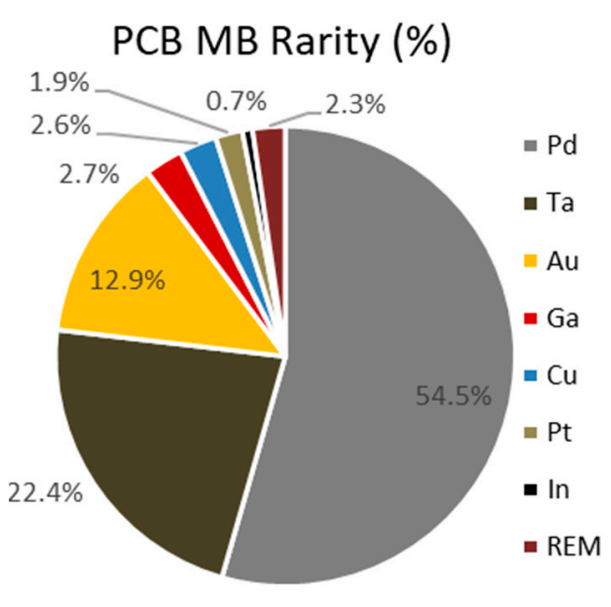

(d)

Figure 2. Results of composition $(\mathbf{a}, \mathbf{b})$ and thermodynamic rarity $(\mathbf{c}, \mathbf{d})$ per element. 


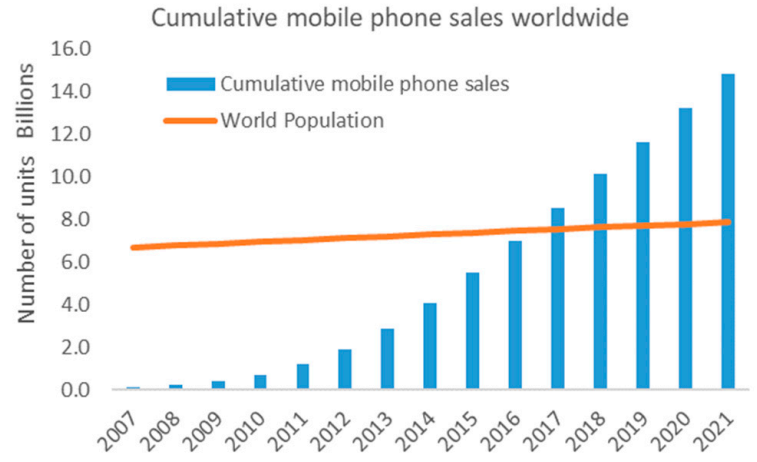

(a)

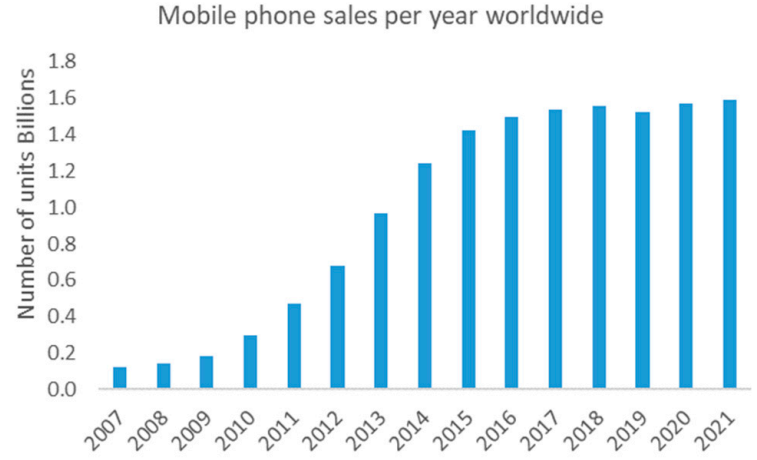

(b)

Figure 3. Mobile Phone sales worldwide since 2007. (a) Annual sales. (b) Cumulative sales [22].

\subsection{Resources Embedded in Mobile Phone PCB Worldwide}

In order to estimate the amount of resources embedded in the PCBs of MP, two sources of information have been taken. On the one hand, the number of MP sold between 2007 and 2021 is 14.8 billion, doubling the world population (Figure 3a). On the other hand, the number of MP put on sale annually considered is 1.5 billion units, which since 2016 has stagnated as shown in Figure $3 \mathrm{~b}$.

Figure A1 (Appendix A) shows the results for each element, and Table 3 shows the results for the highest TR (rows A and B). It indicates that these elements' quantity embedded in MP PCBs increases by approximately $11 \%$ each year.

Table 3. Annual increase in resources embedded in MP PCBs worldwide. Comparison between annual element production and quantity embedded in Mobile Phone PCBs. Extraction data from reference [58].

\begin{tabular}{ccccccccc}
\hline Elements & & Pd & Ta & Au & Ga & Cu & Pt & In \\
\hline (A) Tons embedded & [Tons] & 74 & 602 & 254 & 46 & 98,423 & 5.2 & 25 \\
(B) Tons embedded 2020 & [Tons/yr] & 8 & 64 & 27 & 5 & 10,500 & 0.6 & 2.7 \\
(A)/(B) Annual increase & {$[\%]$} & $10.8 \%$ & $10.6 \%$ & $10.6 \%$ & $10.9 \%$ & $10.7 \%$ & $11.5 \%$ & $10.8 \%$ \\
\hline (C) Annual primary extraction 2020 & {$[$ Tons/yr] } & 210 & 1700 & 3200 & 300 & $20,000,000$ & 170 & 900 \\
(A)/(C) & {$[\%]$} & $35 \%$ & $35 \%$ & $7.9 \%$ & $15.3 \%$ & $0.49 \%$ & $3.1 \%$ & $2.8 \%$ \\
(B)/(C) & {$[\%]$} & $3.8 \%$ & $3.8 \%$ & $0.8 \%$ & $1.7 \%$ & $0.05 \%$ & $0.4 \%$ & $0.3 \%$ \\
\hline
\end{tabular}

This strong annual increase and the short lifespan of the MP -of around four years [23]make such devices an interesting source of valuable raw materials. Accordingly, we now explore how much of the annual production could -theoretically- be covered by the resources embedded in the MP PCBs. Table 3 shows the annual primary extraction of each element in row $C$. In the last two rows, the ratios between row $A$ and $C$, and, $B$ and $C$ are calculated. These ratios indicate the percentage of a year's global extraction that could be replaced if all of the embedded mass between 2007 and 2021 (A/C) could be recovered, or if all of the mass produced in one year could be recovered $(\mathrm{B} / \mathrm{C})$. It is important to emphasize that recovering the entire PCBs from MP is impossible. For example, in Reuter et al., 2018 [60], they only recover $22 \%$ of the metals from a MP in the best case. However, they achieve very high recovery rates for some elements such as $\mathrm{Au}(90-100 \%), \mathrm{Pd}(10-100 \%)$ or Ga $(80-90 \%)$, but much lower for others $-\mathrm{Ta}(0-10 \%)$. Another example is found in Valero-Navazo et al., 2014 [61], in which $\mathrm{Pd}, \mathrm{Au}, \mathrm{Ag}, \mathrm{Cu}, \mathrm{Ni}, \mathrm{Pb}$ and $\mathrm{Sn}$ are recovered with recovery rates between 80 and $95 \%$. As can be observed, the elements with higher TR are not always recovered, for example, Valero-Navazo et al., 2014 does not recover $\mathrm{Ta}$ or $\mathrm{Ga}$, while in Reuter et al., 2018, the recovery efficiencies of $\mathrm{Pd}$ and $\mathrm{Ta}$ are $10 \%$ and Ga $80 \%$ in the worst cases. Therefore, the percentages in Table 3 should be interpreted as 
a theoretical maximum -unreachable- or, from another perspective, as the percentage of the extraction hoarded by the MP PCBs. In addition to the physical limitations, separate collection rates are very low, ranging from 2 to 16\% [61], so high recovery rates are still far from being achieved.

Coincidentally, most elements with the highest ratios are those with the highest TR, i.e., Pd, Ta, Ga, Au, Pt and In, except for $\mathrm{Cu}$. This may be due to the relationship between geological scarcity and low extraction rates. However, this should not necessarily be the case, as it is a result that depends on the composition of the devices to be analyzed. What is important to note is that the recovery of these elements should be prioritized, as they are not only the most critical from the point of view of TR, but if they were recovered, they could make an important contribution to world production. For example, in the case of $\mathrm{Pd}$ and $\mathrm{Ta}$, their contribution to world production could theoretically reach $35 \%$ if the tons incorporated between 2007 and 2021 could be fully recovered. This figure would be $15 \%$ and $8 \%$ for $\mathrm{Ga}$ and $\mathrm{Au}$, respectively. Considering only the tons embedded in a year, the contribution would drop to $3.8 \%$ for $\mathrm{Pd}$ and $\mathrm{Ta}$; and to $1.7 \%$ and $0.8 \%$ for $\mathrm{Ga}$ and $\mathrm{Au}$, respectively.

\section{Conclusions}

The volatility and increase in raw material prices and even the unavailability of some components may jeopardize the energy transition. The search for secondary raw materials and their recovery becomes necessary to alleviate this shortage situation, which could worsen in the future due to ore grade decline, among other factors. In addition, reducing primary extraction would provide other benefits such as less environmental deterioration and greater availability of resources for future generations. To this end, identifying new sources of secondary resources is essential.

This article analyzes the PCBs of the MPs, through the TR. These devices are promising candidates due to their large sales and their short useful life. The use of TR-a physical indicator based on thermodynamics allows obtaining stable values of material criticality in the medium to long term, which can only be influenced by mining technology and knowledge of the earth's crust. This physical point of view is an essential reinforcement of the criticality assessment of any government, based on the importance of the elements for the given economy's region and the supply risks. Being decoupled from these time-varying factors, the TR can help establish long-term policies. Another advantage of the TR is that it allows to classify and quantify the elements in order of criticality, as each element has a unique value. This helps identify products and parts with a high content of critical and valuable materials and is helpful for eco-design.

The results show that $\mathrm{Pd}, \mathrm{Ta}, \mathrm{Au}, \mathrm{Ga}, \mathrm{Cu}, \mathrm{Pt}$ and $\mathrm{In}$ are the highest contribution to TR in MP. All are considered critical by the EC, except for $\mathrm{Cu}$ and Au. In addition, a considerable percentage of the world's production of $\mathrm{Pd}, \mathrm{Ta}, \mathrm{Ga}$ and $\mathrm{Au}$ is hoarded in $\mathrm{MP}$ PCBs. These results show the need for the recovery of these elements, not only for the conservation of TR, (i.e., of the exergy embedded in the most geologically scarce elements) but also for their significant contribution to the world's commodity production. However, $100 \%$ recovery of the resources embedded in the equipment is impossible, so to achieve the maximum recovery rate, it is necessary to develop and promote recycling processes that allow it. However, these processes are energy-intensive and require further thermodynamic analysis. This will be analyzed in a forthcoming paper.

Author Contributions: Conceptualization, J.T.; Investigation, J.T.; Methodology, A.V. (Antonio Valero) and A.V. (Alicia Valero); Writing — original draft, J.T.; Writing—review \& editing, A.V. (Antonio Valero) and A.V. (Alicia Valero). All authors have read and agreed to the published version of the manuscript.

Funding: This research has been funded by the Spanish Ministry of Science and Innovation [grant number PID2020-116851RB-I00].

Conflicts of Interest: The authors declare no conflict of interest. 


\section{Appendix A}

Table A1. Samples composition (from $\mathrm{Ag}$ to $\mathrm{Cu}$ ) in $\mathrm{mg}$ of element per $\mathrm{kg}$ of PCB.

\begin{tabular}{|c|c|c|c|c|c|c|c|c|c|c|c|c|c|c|c|}
\hline References (mg/kg PCB) & $\mathrm{Ag}$ & Al & As & $\mathrm{Au}$ & $\mathbf{B a}$ & $\mathrm{Be}$ & $\mathbf{B i}$ & $\mathrm{Br}$ & $\mathrm{Ca}$ & $\mathrm{Cd}$ & $\mathrm{Ce}$ & $\mathrm{Cl}$ & Co & $\mathrm{Cr}$ & $\mathrm{Cu}$ \\
\hline Chancerel et al., 2009 & 2244 & & & 50 & & & & & & & & & & & \\
\hline Chancerel et al., 2009 & 3573 & & & 368 & & & & & & & & & & & \\
\hline Chancerel et al., 2009 & 5540 & & & 980 & & & & & & & & & & & \\
\hline Kasper et al., 2011 & 600 & 9900 & & 1000 & & & & & & & & & & & 383,300 \\
\hline Kasper et al., 2011 & 500 & 6100 & & 900 & & & & & & & & & & & 378,100 \\
\hline Oguchi et al., 2011 & 2400 & 67,000 & & & 4700 & & 400 & & & & & & 100 & & 96,000 \\
\hline Oguchi et al., 2011 & 3800 & 15,000 & & 1500 & 19,000 & & 440 & & & & & & 280 & & 330,000 \\
\hline Silvas et al., 2015 & 2100 & 2600 & & & 1600 & & & & 900 & & & & & & 355,000 \\
\hline \multicolumn{16}{|l|}{ Ueberschaar et al., 2017 (a) } \\
\hline Ueberschaar et al., 2017 (b) & 1580 & 19,741 & 0.0438 & 529 & 14,778 & 6 & 0.044 & & 38,851 & 0.044 & 0.071 & & 0.044 & & 255,100 \\
\hline Ueberschaar et al., 2017 (b) & 1597 & 42,979 & 21 & 1038 & 19,466 & 66 & 66 & & 27,837 & 2 & 7 & & 253 & & 464,000 \\
\hline Arshadi et al., 2018 & 1470 & 57,930 & 480 & & 3990 & & & 37,950 & 32,760 & & & 5310 & & 1590 & 210,000 \\
\hline Holgersson et al., 2018 & 2640 & 22,736 & 93.3 & 1051 & 2152 & 98.8 & 39.6 & & 1556 & & & & 2.1 & 952.9 & 342,667 \\
\hline Holgersson et al., 2018 & 2773 & 23,003 & 141 & 1083 & 2662 & 138 & 60.6 & & 762 & & & & & 1306.7 & 395,000 \\
\hline Holgersson et al., 2018 & 2500 & & & 1200 & & & & & & 1 & & & & 2000 & 250,000 \\
\hline Holgersson et al., 2018 & 4000 & & & 400 & & & & & & 1 & & & & 3000 & 200,000 \\
\hline Holgersson et al., 2018 & 5000 & & & 1100 & & & & & & 45 & & & & 4000 & 120,000 \\
\hline Holgersson et al., 2018 & 5081 & & & 19 & & & & & & 5 & & & & 801 & 272,402 \\
\hline Holgersson et al., 2018 & 2100 & & & 10 & & & & & & & & & & & 344,900 \\
\hline Holgersson et al., 2018 & 6091 & & & 1591 & & & & & & & & & & & 590,909 \\
\hline Holgersson et al., 2018 & 3301 & & & 570 & & & & & & & & & & & 234,700 \\
\hline Li et al., 2018 & 1380 & 10,000 & & 350 & & & & & & & & & & & 130,000 \\
\hline Gu et al., 2019 & 5200 & & & 600 & & & & & & & & & & & 273,700 \\
\hline Gu et al., 2019 & 600 & & & 800 & & & & & & & & & & & 385,700 \\
\hline Gu et al., 2019 & 1000 & & & 200 & & & & & & & & & & & 566,800 \\
\hline Gu et al., 2019 & 500 & & & 100 & & & & & & & & & & & 398,600 \\
\hline Gu et al., 2019 & 2300 & & & 1400 & & & & & & & & & & & 428,000 \\
\hline Gu et al., 2019 & 300 & & & 900 & & & & & & & & & & & 417,900 \\
\hline Gu et al., 2019 & 300 & & & 100 & & & & & & & & & & & 360,000 \\
\hline Gu et al., 2019 & 1100 & & & 100 & & & & & & & & & & & 408,000 \\
\hline
\end{tabular}


Table A1. Cont.

\begin{tabular}{|c|c|c|c|c|c|c|c|c|c|c|c|c|c|c|c|}
\hline References (mg/kg PCB) & $\mathrm{Ag}$ & Al & As & $\mathrm{Au}$ & $\mathrm{Ba}$ & Be & Bi & $\mathrm{Br}$ & $\mathrm{Ca}$ & $\mathrm{Cd}$ & $\mathrm{Ce}$ & $\mathrm{Cl}$ & Co & $\mathrm{Cr}$ & $\mathrm{Cu}$ \\
\hline Gu et al., 2019 & 3400 & & & & & & & & & & & & & & 319,500 \\
\hline Gu et al., 2019 & 300 & & & 200 & & & & & & & & & & & 657,400 \\
\hline Gu et al., 2019 & & & & & & & & & & & & & & & 80,500 \\
\hline Gu et al., 2019 & 1300 & & & 1000 & & & & & & & & & & & 479,000 \\
\hline Korf et al., 2019 & 8118 & 14,949 & & 18 & 10,739 & & 5.6 & & 33,901 & 5.6 & & & 64 & 1792 & 333,228 \\
\hline Korf et al., 2019 & 4125 & 18,333 & & 28 & 6768 & & 5.6 & & 40,984 & 5.6 & & & 39 & 139 & 232,163 \\
\hline Korf et al., 2019 & 2100 & 2600 & & & & & & & & & & & & & 344,900 \\
\hline Korf et al., 2019 & 600 & 3100 & & 600 & & & & & & & & & & & 395,600 \\
\hline Korf et al., 2019 & 500 & 6100 & & 900 & & & & & & & & & & & 378,100 \\
\hline Korf et al., 2019 & 2400 & 67,000 & & & 4700 & & 400 & & & & & & 100 & & 96,000 \\
\hline Korf et al., 2019 & 3800 & 15,000 & & 1500 & 19,000 & & 440 & & & & & & 280 & & 330,000 \\
\hline Korf et al., 2019 & 1000 & 32,700 & & 600 & 1600 & & & 56,700 & 45,200 & & & 1300 & & 200 & 241,900 \\
\hline Korf et al., 2019 & 430 & 25,200 & 145 & 1280 & 18,000 & 1.8 & 53.8 & & 9480 & 1.7 & 1.7 & & 500 & 123 & 371,000 \\
\hline Korf et al., 2019 & 310 & 10,600 & 258 & 1410 & 19,000 & 0.8 & 39 & & 12,300 & 0.6 & 4.9 & & 540 & 42,000 & 306,000 \\
\hline Korf et al., 2019 & 370 & 17,300 & 111 & 552 & 20,300 & & 15.5 & & 8340 & 0.9 & 2.1 & & 270 & 650 & 494,000 \\
\hline Korf et al., 2019 & 2640 & 22,736 & 93.3 & 1051 & 2152 & 98.8 & 39.6 & & 1556 & & & & 2.1 & 952.9 & 342,667 \\
\hline Korf et al., 2019 & 2773 & 23,003 & 141 & 1083 & 2662 & 138 & 60.6 & & 762 & & & & & 1306.7 & 395,000 \\
\hline Sahan et al., 2019 & 2000 & 10,400 & & 2900 & & & & & & & & & 270 & 3900 & 227,500 \\
\hline Sahan et al., 2019 & 2000 & 11,500 & & 1400 & & & & & & & & & 110 & 330 & 378,000 \\
\hline Sahan et al., 2019 & 4700 & 12,900 & & 1300 & & & & & & & & & 190 & 510 & 404,000 \\
\hline Sahan et al., 2019 & 8300 & 10,700 & & 1800 & & & & & & & & & 110 & 130 & 206,000 \\
\hline Sahan et al., 2019 & 5100 & 11,800 & & 1600 & & & & & & & & & 120 & 290 & 287,500 \\
\hline Sahan et al., 2019 & 3700 & 14,900 & & 1500 & & & & & & & & & 370 & 460 & 305,200 \\
\hline Sahan et al., 2019 & 3200 & 16,600 & & 820 & & & & & & & & & 230 & 170 & 451,400 \\
\hline Sahan et al., 2019 & 3900 & 16,300 & & 1100 & & & & & & & & & 700 & 440 & 313,100 \\
\hline Sahan et al., 2019 & 2600 & 20,100 & & 530 & & & & & & & & & 50 & 440 & 397,700 \\
\hline Sahan et al., 2019 & 5900 & 15,900 & & 1600 & & & & & & & & & 300 & 140 & 282,400 \\
\hline Sahan et al., 2019 & 1700 & 19,700 & & 170 & & & & & & & & & 100 & 15,000 & 409,800 \\
\hline Sahan et al., 2019 & & 6100 & & & & & & & & & & & & & 378,000 \\
\hline Sahan et al., 2019 & 2100 & 2600 & & & & & & & & & & & & & 344,900 \\
\hline Sahan et al., 2019 & & & & & & & & & & & & & & 8500 & 17,700 \\
\hline Sahan et al., 2019 & 1060 & & & 65 & & & & & & & & & & & 408,000 \\
\hline Sahan et al., 2019 & 540 & & & 43 & & & & & & & & & & & 398,600 \\
\hline
\end{tabular}


Table A1. Cont.

\begin{tabular}{|c|c|c|c|c|c|c|c|c|c|c|c|c|c|c|c|}
\hline References (mg/kg PCB) & Ag & Al & As & $\mathbf{A u}$ & $\mathbf{B a}$ & Be & Bi & $\mathrm{Br}$ & $\mathrm{Ca}$ & Cd & $\mathrm{Ce}$ & $\mathrm{Cl}$ & Co & $\mathrm{Cr}$ & $\mathrm{Cu}$ \\
\hline Sahan et al., 2019 & 4700 & 15,200 & & 1400 & & & & & & & & & 200 & 400 & 326,200 \\
\hline Average & 2557 & 17,628 & 148 & 859 & 9626 & 69 & 138 & 47,325 & 18,228 & 6 & 3 & 3305 & 199 & 2985 & 332,464 \\
\hline St deviation & 1886 & 15,301 & 137 & 616 & 7663 & 59 & 178 & 13,258 & 17,311 & 13 & 3 & 2835 & 174 & 7838 & 116,836 \\
\hline Maximum & 8300 & 67,000 & 480 & 2900 & 20,300 & 138 & 440 & 56,700 & 45,200 & 45 & 7 & 5310 & 700 & 42,000 & 657,400 \\
\hline Number of samples & 66 & 43 & 10 & 58 & 18 & 8 & 15 & 2 & 14 & 12 & 5 & 2 & 27 & 31 & 66 \\
\hline
\end{tabular}

Table A2. Sample composition (from Dy to Na) in mg of element per kg of PCBs.

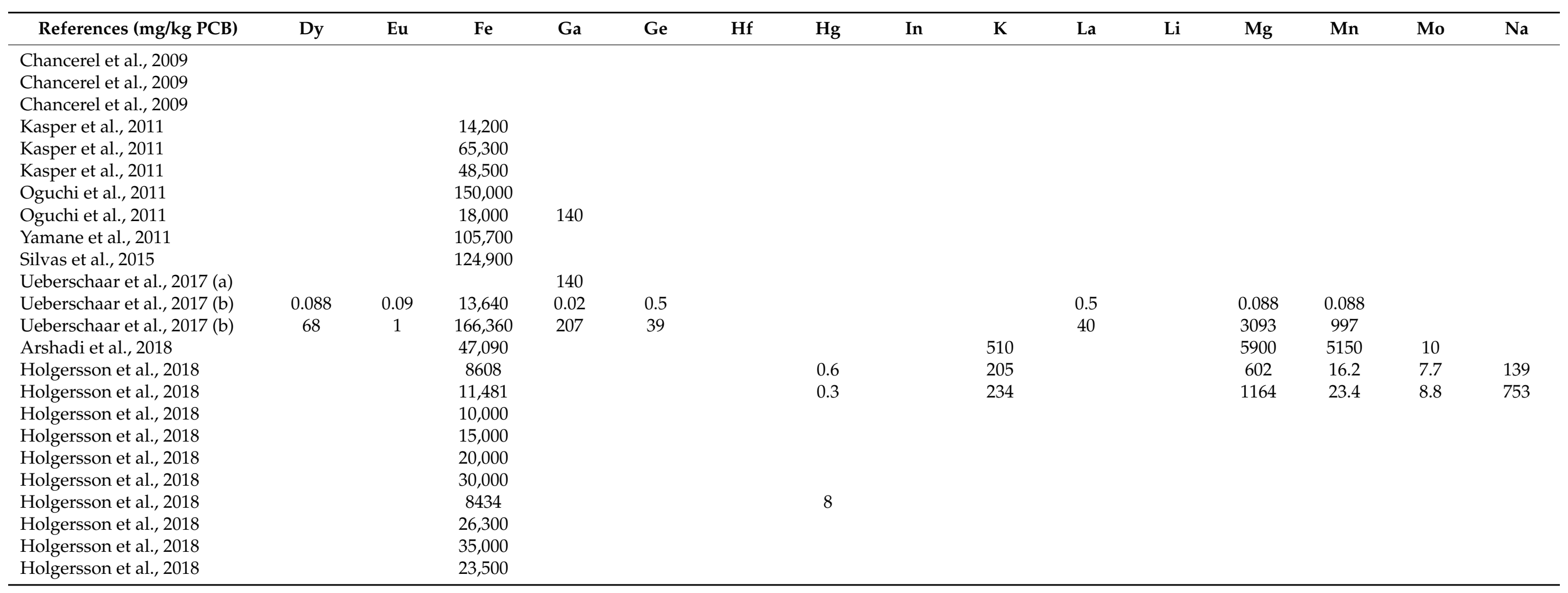


Table A2. Cont.

\begin{tabular}{|c|c|c|c|c|c|c|c|c|c|c|c|c|c|c|c|}
\hline References (mg/kg PCB) & Dy & Eu & $\mathrm{Fe}$ & $\mathrm{Ga}$ & $\mathrm{Ge}$ & Hf & $\mathrm{Hg}$ & In & K & La & $\mathbf{L i}$ & $\mathrm{Mg}$ & Mn & Mo & $\mathbf{N a}$ \\
\hline Li et al., 2018 & & & 50,000 & & & & & & & & & & & & \\
\hline Gu et al., 2019 & & & & & & & & & & & & & & & \\
\hline Gu et al., 2019 & & & 42,700 & & & & & & & & & & & & \\
\hline Gu et al., 2019 & & & 2400 & & & & & & & & & & & & \\
\hline Gu et al., 2019 & & & & & & & & & & & & & & & \\
\hline Gu et al., 2019 & & & 46,000 & & & & & & & & & & & & \\
\hline Gu et al., 2019 & & & & & & & & & & & & & & & \\
\hline Gu et al., 2019 & & & 10,500 & & & & & & & & & & & & \\
\hline Gu et al., 2019 & & & 19,400 & & & & & & & & & & & & \\
\hline Gu et al., 2019 & & & 15,100 & & & & & & & & & & & & \\
\hline Gu et al., 2019 & & & 500 & & & & & & & & & & & & \\
\hline Gu et al., 2019 & & & 5000 & & & & & & & & & & & & \\
\hline Korf et al., 2019 & & & 15,089 & 210 & & & 12 & 5.6 & 236 & & 13 & 635 & 654 & & 897 \\
\hline Korf et al., 2019 & & & 5366 & 184 & & & 7 & 5.6 & 347 & & 15 & 947 & 569 & & 1197 \\
\hline Korf et al., 2019 & & & 105,700 & & & & & & & & & & & & \\
\hline Korf et al., 2019 & & & 14,200 & & & & & & & & & & & & \\
\hline Korf et al., 2019 & & & 65,300 & & & & & & & & & & & & \\
\hline Korf et al., 2019 & & & 18,000 & 140 & & & & & & & & & & & \\
\hline Korf et al., 2019 & & & 1600 & & & & & & 300 & & & 1900 & & & \\
\hline Korf et al., 2019 & & & 157,200 & 180 & 12.4 & 17.9 & & 141 & & 4.6 & 35 & 701 & 2407 & 244 & 412 \\
\hline Korf et al., 2019 & & & 251,000 & 267 & 20 & 23 & 0.34 & 134 & & 6.3 & 41 & 1680 & 4900 & 265 & 400 \\
\hline Korf et al., 2019 & & & 18,900 & 103 & 3.9 & 28.2 & & 144 & & 2.9 & 37 & 2000 & 480 & 75 & 391 \\
\hline Korf et al., 2019 & & & 8608 & & & & 0.6 & & 205 & & & 602 & 16.2 & 7.7 & 139 \\
\hline Korf et al., 2019 & & & 11,481 & & & & 0.3 & & 234 & & & 1164 & 23.4 & 8.8 & 753 \\
\hline Sahan et al., 2019 & & & 23,600 & & & & & & & & & & & & \\
\hline Sahan et al., 2019 & & & 20,400 & & & & & & & & & & & & \\
\hline Sahan et al., 2019 & & & 37,200 & & & & & & & & & & & & \\
\hline Sahan et al., 2019 & & & 33,900 & & & & & & & & & & & & \\
\hline Sahan et al., 2019 & & & 48,400 & & & & & & & & & & & & \\
\hline Sahan et al., 2019 & & & 10,000 & & & & & & & & & & & & \\
\hline Sahan et al., 2019 & & & 5000 & & & & & & & & & & & & \\
\hline Sahan et al., 2019 & & & 14,800 & & & & & & & & & & & & \\
\hline Sahan et al., 2019 & & & 6400 & & & & & & & & & & & & \\
\hline
\end{tabular}


Table A2. Cont.

\begin{tabular}{|c|c|c|c|c|c|c|c|c|c|c|c|c|c|c|c|}
\hline References (mg/kg PCB) & Dy & $\mathrm{Eu}$ & $\mathrm{Fe}$ & Ga & $\mathrm{Ge}$ & Hf & $\mathbf{H g}$ & In & $\mathbf{K}$ & La & $\mathbf{L i}$ & $\mathrm{Mg}$ & Mn & Mo & $\mathrm{Na}$ \\
\hline Sahan et al., 2019 & & & 11,900 & & & & & & & & & & & & \\
\hline Sahan et al., 2019 & & & 46,300 & & & & & & & & & & & & \\
\hline Sahan et al., 2019 & & & 10,100 & & & & & & & & & & & & \\
\hline Sahan et al., 2019 & & & 34,200 & & & & & & & & & & & & \\
\hline Sahan et al., 2019 & & & 48,500 & & & & & & & & & & & & \\
\hline Sahan et al., 2019 & & & 105,700 & & & & & & & & & & & & \\
\hline Sahan et al., 2019 & & & & & & & & & & & & & & & \\
\hline Sahan et al., 2019 & & & 2800 & & & & & & & & & & & & \\
\hline Sahan et al., 2019 & & & 14,600 & & & & & & & & & & & & \\
\hline Average & 34 & 1 & 40,675 & 157 & 15 & 23 & 4 & 86 & 284 & 11 & 28 & 1568 & 1270 & 78 & 565 \\
\hline St deviation & 48 & 1 & 50,004 & 72 & 15 & 5 & 5 & 74 & 104 & 16 & 13 & 1529 & 1882 & 111 & 358 \\
\hline Minimum & 0.088 & 0.09 & 500 & 0.02 & 0.5 & 17.9 & 0.3 & 5.6 & 205 & 0.5 & 13 & 0.088 & 0.088 & 7.7 & 139 \\
\hline Maximum & 68 & 1 & 251,000 & 267 & 39 & 28.2 & 12 & 144 & 510 & 40 & 41 & 5900 & 5150 & 265 & 1197 \\
\hline Number of samples & 2 & 2 & 61 & 10 & 5 & 3 & 8 & 5 & 8 & 5 & 5 & 13 & 12 & 8 & 9 \\
\hline
\end{tabular}

Table A3. Sample composition (from Nd to $\mathrm{Sr}$ ) in mg of element per $\mathrm{kg}$ of PCBs.

\begin{tabular}{|c|c|c|c|c|c|c|c|c|c|c|c|c|c|c|c|}
\hline References (mg/kg PCB) & $\mathrm{Nd}$ & $\mathbf{N i}$ & $\mathbf{P}$ & $\mathrm{Pb}$ & Pd & $\operatorname{Pr}$ & $\mathbf{P t}$ & $\mathbf{R h}$ & $\mathbf{S}$ & $\mathrm{Sb}$ & $\mathrm{Sc}$ & $\mathrm{Si}$ & $\mathrm{Sm}$ & Sn & Sr \\
\hline Chancerel et al., 2009 & & & & & 241 & & & & & & & & & & \\
\hline Chancerel et al., 2009 & & & & & 287 & & & & & & & & & & \\
\hline Chancerel et al., 2009 & & & & & 285 & & 7 & & & & & & & & \\
\hline Kasper et al., 2011 & & 16,700 & & 12,600 & & & & & & & & & & 31,100 & \\
\hline Kasper et al., 2011 & & 25,400 & & 12,300 & & & & & & & & & & 25,500 & \\
\hline Oguchi et al., 2011 & & & & 19,000 & & & & & & & & & & 34,000 & 300 \\
\hline Oguchi et al., 2011 & & & & 13,000 & 300 & & & & & & & & & 35,000 & 430 \\
\hline Silvas et al., 2015 & & 34,100 & & 18,700 & & & & & & & & & & 33,900 & \\
\hline \multicolumn{16}{|l|}{ Ueberschaar et al., 2017 (a) } \\
\hline Ueberschaar et al., 2017 (b) & 0.088 & 8390 & & 3707 & 103 & 0.088 & 1.75 & & & 1858 & & 108,492 & 0.088 & 17,640 & \\
\hline Ueberschaar et al., 2017 (b) & 1162 & 37,628 & & 132 & 56 & 85 & 1 & & & 10 & & 112,800 & 8 & 26,948 & \\
\hline Arshadi et al., 2018 & 400 & 2790 & 1000 & 11,190 & & & & & 1900 & 2660 & & 94,250 & & 23,540 & 400 \\
\hline Holgersson et al., 2018 & 9.7 & 11,600 & 910 & 3747 & 119 & & 4.3 & 5.7 & & 543 & 0.4 & 66,150 & & 19,267 & 108 \\
\hline
\end{tabular}


Table A3. Cont.

\begin{tabular}{|c|c|c|c|c|c|c|c|c|c|c|c|c|c|c|c|}
\hline References (mg/kg PCB) & Nd & $\mathrm{Ni}$ & $\mathbf{P}$ & $\mathrm{Pb}$ & Pd & $\operatorname{Pr}$ & $\mathbf{P t}$ & $\mathbf{R h}$ & $\mathrm{S}$ & $\mathrm{Sb}$ & Sc & Si & Sm & Sn & $\mathrm{Sr}$ \\
\hline Holgersson et al., 2018 & 60.7 & 15,433 & 1441 & 260 & 55.4 & & 0.8 & 8.5 & & 30.4 & 0.6 & 56,971 & & 32,200 & 82.5 \\
\hline Holgersson et al., 2018 & & & & 12,000 & 200 & & & & & 1000 & & & & & \\
\hline Holgersson et al., 2018 & & & & 17,000 & 1100 & & & & & 200 & & & & & \\
\hline Holgersson et al., 2018 & & & & 9000 & 300 & & & & & 500 & & & & & \\
\hline Holgersson et al., 2018 & & & & 11,000 & 3 & & & & & 2500 & & & & & \\
\hline Holgersson et al., 2018 & & & & 1618 & 5 & & & & & 22 & & & & & \\
\hline Holgersson et al., 2018 & & & & 18,700 & & & & & & & & & & & \\
\hline Holgersson et al., 2018 & & & & 13,636 & 955 & & & & & & & & & & \\
\hline Holgersson et al., 2018 & & & & 9900 & 294 & & 30 & & & & & & & & \\
\hline Li et al., 2018 & & 1000 & & 3000 & 210 & & & & & & & & & 5000 & \\
\hline Gu et al., 2019 & & & & & 400 & & & & & & & & & & \\
\hline Gu et al., 2019 & & 25,400 & & 12,200 & & & & & & & & & & 25,800 & \\
\hline Gu et al., 2019 & & & & & 100 & & & & & & & & & 14,000 & \\
\hline Gu et al., 2019 & & 4000 & & & & & & & & & & & & & \\
\hline Gu et al., 2019 & & 6000 & & 600 & 100 & & & & & & & & & 26,000 & \\
\hline Gu et al., 2019 & & 300 & & & & & & & & & & & & 200 & \\
\hline Gu et al., 2019 & & 8600 & & 12,100 & 600 & & & & & & & & & & \\
\hline Gu et al., 2019 & & 3900 & & 13,600 & 100 & & & & & & & & & 16,000 & \\
\hline Gu et al., 2019 & & 100 & & 6100 & & & & & & & & & & 8600 & \\
\hline Gu et al., 2019 & & 8000 & & & 100 & & & & & & & & & 20,000 & \\
\hline Korf et al., 2019 & & 13,454 & & 1405 & 5,6 & & & & & 44 & & & & & 334 \\
\hline Korf et al., 2019 & & 6870 & & 2495 & 5,6 & & & & & 8 & & & & & 372 \\
\hline Korf et al., 2019 & & 26,300 & & 18,700 & & & & & & & & & & 33,900 & \\
\hline Korf et al., 2019 & & 34,200 & & 11,700 & & & & & & & & & & 20,900 & \\
\hline Korf et al., 2019 & & 16,700 & & 12,600 & & & & & & & & & & 31,100 & \\
\hline Korf et al., 2019 & & 25,400 & & 12,300 & & & & & & & & & & 25,500 & \\
\hline Korf et al., 2019 & & & & 19,000 & & & & & & & & & & 34,000 & 300 \\
\hline Korf et al., 2019 & & & & 13,000 & 300 & & & & & & & & & 35,000 & 430 \\
\hline Korf et al., 2019 & 100 & 2900 & 4000 & 8900 & & & & & 1900 & & & 104,800 & & 14,200 & 500 \\
\hline Korf et al., 2019 & 44 & 41,500 & & 283 & 99 & & 7.3 & & & 12.2 & 11 & 60,000 & & 38,100 & 284 \\
\hline Korf et al., 2019 & 32 & 57,000 & & 610 & 178 & & 25 & & & 9.8 & 12 & 80,200 & & 31,400 & 233 \\
\hline Korf et al., 2019 & 9.5 & 82,900 & & 597 & 100 & & 5.3 & & & 3.16 & 17 & 45,300 & & 41,700 & 372 \\
\hline Korf et al., 2019 & 9.7 & 11,600 & 910 & 3747 & 119 & & 4.3 & 5.7 & & 543 & 0.4 & 66,150 & & 19,267 & 108 \\
\hline Korf et al., 2019 & 60.7 & 15,433 & 1441 & 260 & 55.4 & & 0.8 & 8.5 & & 30.4 & 0.6 & 56,971 & & 32,200 & 82.5 \\
\hline
\end{tabular}


Table A3. Cont.

\begin{tabular}{|c|c|c|c|c|c|c|c|c|c|c|c|c|c|c|c|}
\hline References (mg/kg PCB) & Nd & $\mathrm{Ni}$ & $\mathbf{P}$ & $\mathrm{Pb}$ & Pd & Pr & $\mathbf{P t}$ & $\mathbf{R h}$ & $\mathbf{S}$ & $\mathrm{Sb}$ & Sc & $\mathrm{Si}$ & Sm & Sn & Sr \\
\hline Sahan et al., 2019 & & 32,300 & & 1600 & 10 & & 32 & & & & & & & 62,700 & \\
\hline Sahan et al., 2019 & & 13,600 & & 1000 & DL & & 22 & & & & & & & 34,300 & \\
\hline Sahan et al., 2019 & & 23,800 & & 7300 & 40 & & 26 & & & & & & & 51,800 & \\
\hline Sahan et al., 2019 & & 37,700 & & 16,700 & 220 & & 50 & & & & & & & 26,200 & \\
\hline Sahan et al., 2019 & & 11,000 & & 16,300 & 360 & & 33 & & & & & & & 29,600 & \\
\hline Sahan et al., 2019 & & 15,800 & & 17,900 & 400 & & 19 & & & & & & & 35,500 & \\
\hline Sahan et al., 2019 & & 31,900 & & 14,600 & 820 & & 7 & & & & & & & 29,700 & \\
\hline Sahan et al., 2019 & & 27,000 & & 10,000 & 470 & & 15 & & & & & & & 13,000 & \\
\hline Sahan et al., 2019 & & 17,000 & & 27,300 & DL & & 26 & & & & & & & 33,000 & \\
\hline Sahan et al., 2019 & & 15,000 & & 15,600 & 390 & & 36 & & & & & & & 27,100 & \\
\hline Sahan et al., 2019 & & 20,100 & & 1900 & 140 & & 26 & & & & & & & 13,700 & \\
\hline Sahan et al., 2019 & & 25,400 & & 12,300 & & & & & & & & & & 25,500 & \\
\hline Sahan et al., 2019 & & 26,300 & & 18,700 & & & & & & & & & & 33,900 & \\
\hline Sahan et al., 2019 & & 30,200 & & 5800 & & & & & & & & & & & \\
\hline Sahan et al., 2019 & & 3900 & & 13,600 & 50 & & & & & & & & & 16,000 & \\
\hline Sahan et al., 2019 & & 3960 & & & & & & & & & & & & & \\
\hline Average & 172 & 21,068 & 1617 & 10,234 & 251 & 43 & 18 & 7 & 1900 & 587 & 6 & 77,462 & 4 & 26,677 & 289 \\
\hline St deviation & 347 & 16,147 & 1193 & 6859 & 245 & 60 & 13 & 2 & 0 & 895 & 7 & 23,840 & 6 & 10,939 & 138 \\
\hline Minimum & 0.088 & 100 & 910 & 132 & 3 & 0.088 & 0.8 & 5.7 & 1900 & 3.16 & 0.4 & 45,300 & 0.088 & 200 & 82.5 \\
\hline Maximum & 1162 & 82,900 & 4000 & 27,300 & 1100 & 85 & 50 & 8.5 & 1900 & 2660 & 17 & 112,800 & 8 & 62,700 & 500 \\
\hline Number of samples & 11 & 52 & 6 & 59 & 42 & 2 & 25 & 4 & 2 & 17 & 7 & 11 & 2 & 50 & 15 \\
\hline
\end{tabular}

Table A4. Sample composition (from Ta to $\mathrm{Zr}$ ) in mg of element per $\mathrm{kg}$ of PCBs.

\begin{tabular}{|c|c|c|c|c|c|c|c|c|c|c|c|}
\hline References (mg/kg PCB) & Ta & $\mathrm{Tb}$ & Te & Th & $\mathrm{Ti}$ & $\mathbf{V}$ & $\mathbf{W}$ & $\mathbf{Y}$ & $\mathrm{Zn}$ & $\mathrm{Zr}$ & Measured \% of Total PCB Mass \\
\hline Chancerel et al., 2009 & & & & & & & & & & & $0.25 \%$ \\
\hline Chancerel et al., 2009 & & & & & & & & & & & $0.42 \%$ \\
\hline Chancerel et al., 2009 & & & & & & & & & & & $0.68 \%$ \\
\hline Kasper et al., 2011 & & & & & & & & & 9700 & & $53.02 \%$ \\
\hline Kasper et al., 2011 & & & & & & & & & 18,200 & & $51.55 \%$ \\
\hline
\end{tabular}


Table A4. Cont.

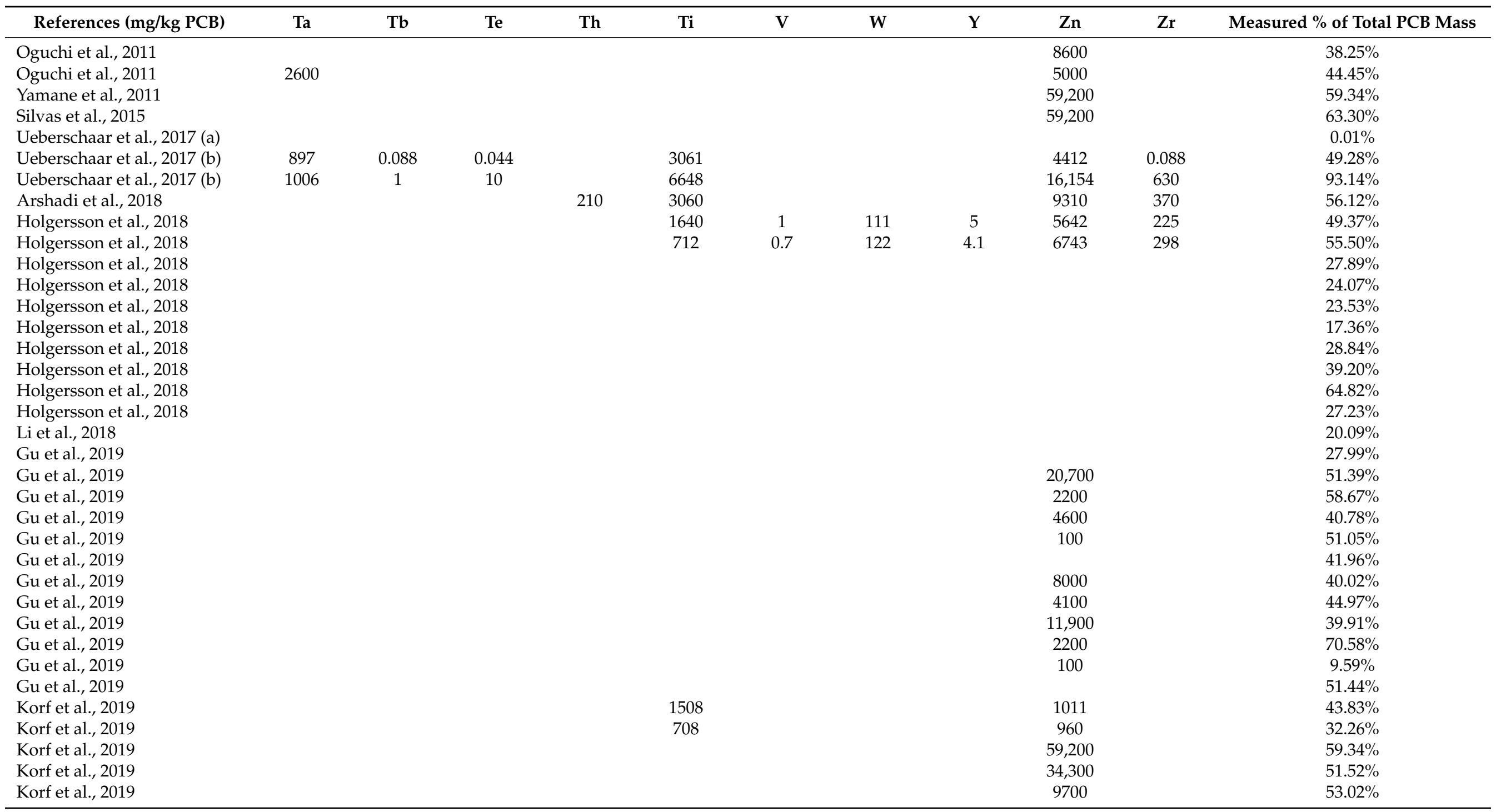


Table A4. Cont.

\begin{tabular}{|c|c|c|c|c|c|c|c|c|c|c|c|}
\hline References (mg/kg PCB) & Ta & $\mathrm{Tb}$ & $\mathrm{Te}$ & Th & Ti & $\mathbf{V}$ & $\mathbf{W}$ & $\mathbf{Y}$ & Zn & $\mathrm{Zr}$ & Measured $\%$ of Total PCB Mass \\
\hline Korf et al., 2019 & & & & & & & & & 18,200 & & $51.55 \%$ \\
\hline Korf et al., 2019 & & & & & & & & & 8600 & & $38.25 \%$ \\
\hline Korf et al., 2019 & 2600 & & & & & & & & 5000 & & $44.45 \%$ \\
\hline Korf et al., 2019 & & & & & 1500 & & & & 700 & 300 & $52.48 \%$ \\
\hline Korf et al., 2019 & 2800 & & & & 6450 & 140 & 1110 & 43 & 3770 & 692 & $74.29 \%$ \\
\hline Korf et al., 2019 & 2000 & & & & 7100 & 187 & 860 & 40 & 5600 & 910 & $83.76 \%$ \\
\hline Korf et al., 2019 & 2330 & & & & 7300 & 12.8 & 1740 & 230 & 69,000 & 1280 & $81.70 \%$ \\
\hline Korf et al., 2019 & & & & & 1640 & 1 & 111 & 5 & 5642 & 225 & $49.37 \%$ \\
\hline Sahan et al., 2019 & & & & & & & & & 28,100 & & $48.72 \%$ \\
\hline Sahan et al., 2019 & & & & & & & & & 8200 & & $46.36 \%$ \\
\hline Sahan et al., 2019 & & & & & & & & & 21,200 & & $38.83 \%$ \\
\hline Sahan et al., 2019 & & & & & & & & & 2300 & & $48.17 \%$ \\
\hline Sahan et al., 2019 & & & & & & & & & 17,800 & & $57.07 \%$ \\
\hline Sahan et al., 2019 & & & & & & & & & 3500 & & $29.78 \%$ \\
\hline Sahan et al., 2019 & & & & & & & & & 7200 & & $38.82 \%$ \\
\hline Sahan et al., 2019 & & & & & & & & & 30,200 & & $44.82 \%$ \\
\hline Sahan et al., 2019 & & & & & & & & & 67,000 & & $65.39 \%$ \\
\hline Sahan et al., 2019 & & & & & & & & & 13,600 & & $38.81 \%$ \\
\hline Sahan et al., 2019 & & & & & & & & & 18,900 & & $53.54 \%$ \\
\hline Sahan et al., 2019 & & & & & & & & & 18,200 & & $51.40 \%$ \\
\hline Sahan et al., 2019 & & & & & & & & & 59,200 & & $59.34 \%$ \\
\hline Sahan et al., 2019 & & & & & & & & & 1000 & & $6.32 \%$ \\
\hline Sahan et al., 2019 & & & & & & & & & 4100 & & $44.96 \%$ \\
\hline Sahan et al., 2019 & & & & & & & & & 4570 & & $40.77 \%$ \\
\hline Sahan et al., 2019 & & & & & & & & & 17,000 & & $44.86 \%$ \\
\hline Average & 2033 & 1 & 5 & 210 & 3234 & 49 & 597 & 47 & 16,164 & 475 & $64.35 \%$ \\
\hline St deviation & 782 & 1 & 7 & - & 2641 & 79 & 654 & 82 & 18,616 & 369 & \\
\hline Minimum & 897 & 0.088 & 0.044 & 210 & 708 & 0.7 & 111 & 4.1 & 100 & 0.088 & \\
\hline Maximum & 2800 & 1 & 10 & 210 & 7300 & 187 & 1740 & 230 & 69,000 & 1280 & \\
\hline Number of samples & 7 & 2 & 2 & 1 & 13 & 7 & 7 & 7 & 54 & 11 & \\
\hline
\end{tabular}


Element content in PCB MP worldwide between 2007-2021 (14.8 billions)

98,424

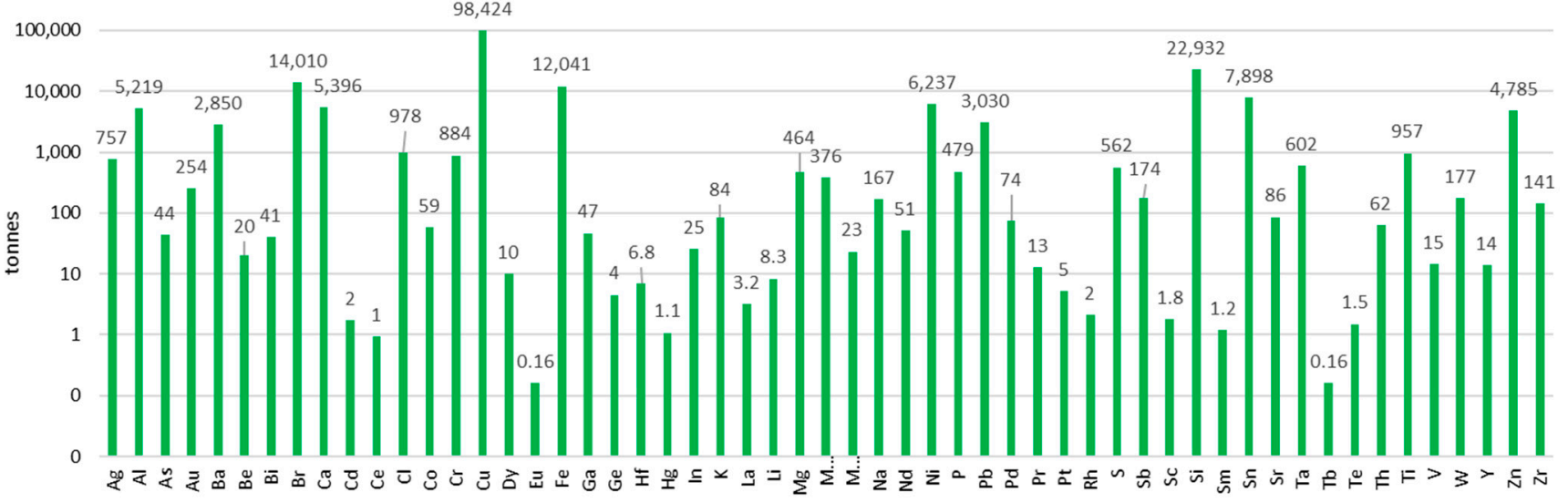

(a)

Annual increase of the Element content in PCB MP worldwide (2020 production: 1.5 billions)

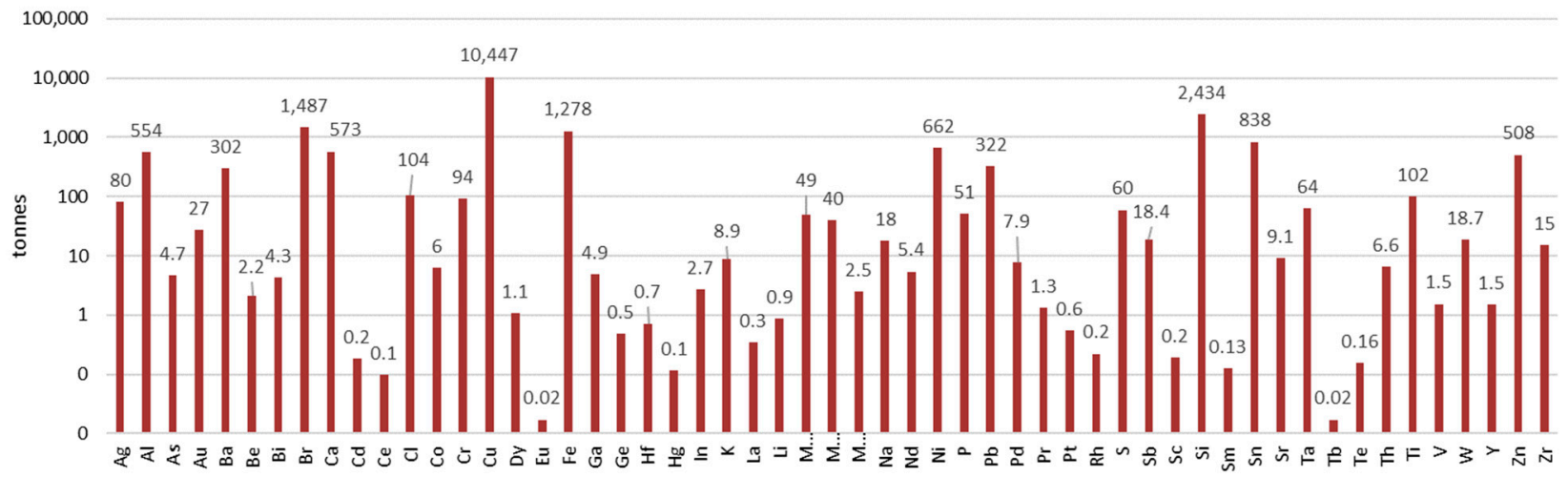

(b)

Figure A1. Approach of the element mass (a) and its annual increase (b) in Mobile Phone Printed Circuit Boards worldwide.

\section{References}

1. Eurostat EU Trade in Raw Materials, 2020-2020. Available online: https:/ / ec.europa.eu/eurostat/statistics-explained/index. php?title=Extra-EU_trade_in_raw_materials\#: \{\}:text=In $\% 202020 \% 2 \mathrm{C} \% 20$ the $\% 20$ value $\% 20$ of,deficit $\% 20$ of $\% 20$ EUR $\% 2026.4 \% 2$ Obillion (accessed on 25 October 2021).

2. International Energy Agency. World Energy Outlook 2021; International Energy Agency: Paris, France, 2021. Available online: https:/ / www.iea.org/reports/world-energy-outlook-2021 (accessed on 25 October 2021).

3. Kemp, J. Rising Electricity Prices in Europe. Available online: https://www.reuters.com/business/energy/europes-risingenergy-prices-will-force-factory-closures-kemp-2021-10-01/ (accessed on 25 October 2021).

4. Meredith, S. Rising Electricity Prices in Europe. Available online: https://www.cnbc.com/2021/09/16/europes-energy-crisis-ismaking-the-market-nervous-ahead-of-winter.html (accessed on 25 October 2021).

5. Tagliapietra, S.; Zachmann, G. Rising Electricity Prices in Europe. Available online: https://www.bruegel.org/2021/09/iseuropes-gas-and-electricity-price-surge-a-one-off/ (accessed on 25 October 2021).

6. Liboreiro, J.; de Filippis, A. Rising Electricity Prices in Europe. Available online: https://www.euronews.com/2021/09/23/whyeurope-s-energy-prices-are-soaring-and-could-get-much-worse (accessed on 25 October 2021).

7. Fitch Ratings Rising Natural Gas Prices in Europe. Available online: https://www.fitchratings.com/research/corporate-finance/ record-high-gas-prices-affect-many-european-corporate-sectors-22-09-2021 (accessed on 25 October 2021).

8. Autotraveler Rising Fuel Prices in Europe. Available online: https://autotraveler.ru/en/spravka/fuel-price-in-europe.html (accessed on 25 October 2021).

9. The News 24 Rising Food Price. Available online: https://then24.com/2021/06/28/the-imf-warns-that-the-rise-in-food-priceshas-only-just-begun-for-consumers / (accessed on 25 October 2021).

10. Amaro, S. Rising Food Price. Available online: https://www.cnbc.com/2021/07/27/imf-warns-that-inflation-could-prove-tobe-persistent.html (accessed on 25 October 2021). 
11. Baffes, J.; Chian Koh, W. Rising Fertilizers Prices. Available online: https://blogs.worldbank.org/opendata/fertilizer-pricesexpected-stay-high-over-remainder-2021 (accessed on 25 October 2021).

12. Fortuna, G. Rising Livestook Food Prices. Available online: https://www.euractiv.com/section/agriculture-food/news/animalfeed-spike-worries-eu-countries / (accessed on 25 October 2021).

13. Konings, J.; Luman, R. Rising Shipping Costs. Available online: https://think.ing.com/articles/the-rise-and-rise-of-globalshipping-costs (accessed on 25 October 2021).

14. Longley, A.; Bosley, C.; Hipwell, D. Rising Shipping Costs. Available online: https:/ time.com/6073233/shipping-costs-surgeprice-hike-goods/ (accessed on 25 October 2021).

15. Reuters Semiconductor Shortage in Europe. Available online: https://www.euronews.com/next/2021/08/03/globalsemiconductor-shortage-more-challenging-times-ahead-for-europe-s-major-carmakers (accessed on 25 October 2021).

16. Attinasi, M.G.; de Stefani, R.; Frohm, E.; Gunnella, V.; Koester, G.; Melemenidis, A.; Tóth, M. Semiconductor Shotage in Europe. Available online: https://www.ecb.europa.eu/pub/economic-bulletin/focus/2021/html/ecb.ebbox202104_06 \{\}780de2a8fb. en.html (accessed on 25 October 2021).

17. Valero, A.; Valero, A.; Calvo, G.; Ortego, A. Material Bottlenecks in the Future Development of Green Technologies. Renew. Sustain. Energy Rev. 2018, 93, 178-200. [CrossRef]

18. International Energy Agency. World Energy Outlook 2019; International Energy Agency: Paris, France, 2019. Available online: https: / / www.iea.org/reports/world-energy-outlook-2019 (accessed on 25 October 2021).

19. International Energy Agency. The Role of Critical Minerals in Clean Energy Transitions; World Energy Outlook Special Report; International Energy Agency: Paris, France, 2021.

20. Henckens, T. Scarce Mineral Resources: Extraction, Consumption and Limits of Sustainability. Resour. Conserv. Recycl. 2021, 169, 5511. [CrossRef]

21. International Energy Agency Global Investments in Oil and Gas Upstream in Nominal Terms and Percentage Change from Previous Year, 2010-2020. Available online: https:/ / www.iea.org/data-and-statistics/charts/global-investments-in-oil-and-gasupstream-in-nominal-terms-and-percentage-change-from-previous-year-2010-2020 (accessed on 25 October 2021).

22. O'Dea, S. Mobile Phone Sales between 2007 and 2021. Available online: https://www.statista.com/statistics/263437/globalsmartphone-sales-to-end-users-since-2007/ (accessed on 25 October 2021).

23. Bakker, C.; Wang, F.; Huisman, J.; den Hollander, M. Products That Go Round: Exploring Product Life Extension through Design. J. Clean Prod. 2014, 69, 10-16. [CrossRef]

24. Li, H.; Eksteen, J.; Oraby, E. Hydrometallurgical Recovery of Metals from Waste Printed Circuit Boards (WPCBs): Current Status and Perspectives-A Review. Resour. Conserv. Recycl. 2018, 139, 122-139. [CrossRef]

25. Sahan, M.; Kucuker, M.A.; Demirel, B.; Kuchta, K.; Hursthouse, A. Determination of Metal Content of Waste Mobile Phones and Estimation of Their Recovery Potential in Turkey. Int. J. Environ. Res. Public Health 2019, 16, 887. [CrossRef]

26. Fairphone $70 \%$ of the Carbon Footprint Is in the PCB of Mobile Phones. Available online: https://www.fairphone.com/es/2020 /07/31/how-sustainable-is-the-fairphone-3 (accessed on 25 October 2021).

27. Gu, F.; Summers, P.A.; Hall, P. Recovering Materials from Waste Mobile Phones: Recent Technological Developments. J. Clean. Prod. 2019, 237, 117657. [CrossRef]

28. Calvo, G.; Valero, A.; Valero, A. Thermodynamic Approach to Evaluate the Criticality of Raw Materials and Its Application through a Material Flow Analysis in Europe. J. Ind. Ecol. 2018, 22, 839-852. [CrossRef]

29. European Commission Critical Raw Materials Resilience: Charting a Path towards Greater Security and Sustainability; Brussels, Belgium. 2020. Available online: https:/ / eur-lex.europa.eu/legal-content/EN/TXT/PDF/?uri=CELEX:52020DC0474\&from=EN (accessed on 25 October 2021).

30. Singapore (Bloomberg) Silicon Price Rises 300\%. Available online: https://newsbeezer.com/singapore/the-300-percent-increasein-silicon-causes-another-price-shock-for-the-global-economy-economy-news-top-stories/ (accessed on 25 October 2021).

31. Macrotrends Historical Copper Prices. Available online: https://www.macrotrends.net/1476/copper-prices-historical-chart-data (accessed on 25 October 2021).

32. Haque, N.; Hughes, A.; Lim, S.; Vernon, C. Rare Earth Elements: Overview of Mining, Mineralogy, Uses, Sustainability and Environmental Impact. Resources 2014, 3, 614-635. [CrossRef]

33. European Commission. Directorate-General for Internal Market, Industry, Entrepreneurship and SMEs. Study on the Review of the List of Critical Raw Materials. Executive Summary. 2017. Available online: https://data.europa.eu/doi/10.2873/876644 (accessed on 25 October 2021).

34. Calvo, G.; Mudd, G.; Valero, A.; Valero, A. Decreasing Ore Grades in Global Metallic Mining: A Theoretical Issue or a Global Reality? Resources 2016, 5, 36. [CrossRef]

35. Palacios, J.L.; Calvo, G.; Valero, A.; Valero, A. The Cost of Mineral Depletion in Latin America: An Exergoecology View. Resour. Policy 2018, 59, 117-124. [CrossRef]

36. Valero Capilla, A.; Valero Delgado, A. Thanatia. The Destiny of the Earths Mineral Resources. A Thermodynamic Cradle-to-Cradle Assessment; World Scientific: Singapore, 2015; ISBN 978-9814273930.

37. Valero, A.; Valero, A. Thanatia, The Destiny of the Earth's Mineral Resources: A Cradle to Cradle Assessment; World Scientific Publishing: Singapore, 2014; ISBN 978-981-4273-93-0.

38. Valero, A.; Valero, A. Thermodynamic Rarity and the Loss of Mineralwealth. Energies 2015, 8, 821-836. [CrossRef] 
39. Valero, A.; Valero, A. Thermodynamic Rarity and Recyclability of Raw Materials in the Energy Transition: The Need for an In-Spiral Economy. Entropy 2019, 21, 873. [CrossRef]

40. Valero, A.; Valero, A.; Calvo, G. The Material Limits of Energy Transition: Thanatia; Springer Nature: Cham, Switzerland, 2021; ISBN 978-3-030798532-1.

41. Valero, A.; Valero, A.; von Gries, N. "Composed Thermodynamic Rarity" of the Materials in Electric and Electronic Equipment. In Proceedings of the ECOS 2016-The 29th International Conference on Efficiency, Cost, Optimization, Simulation and Environmental Impact of Energy Systems, Portoroz, Slovenia, 23 June 2016.

42. Ortego, A.; Valero, A.; Valero, A.; Restrepo, E. Vehicles and Critical Raw Materials: A Sustainability Assessment Using Thermodynamic Rarity. J. Ind. Ecol. 2018, 22, 1005-1015. [CrossRef]

43. Ortego, A.; Valero, A.; Valero, A.; Iglesias, M. Downcycling in Automobile Recycling Process: A Thermodynamic Assessment. Resour. Conserv. Recycl. 2018, 136, 24-32. [CrossRef]

44. Horta Arduin, R.; Mathieux, F.; Huisman, J.; Blengini, G.A.; Charbuillet, C.; Wagner, M.; Baldé, C.P.; Perry, N. Novel Indicators to Better Monitor the Collection and Recovery of (Critical) Raw Materials in WEEE: Focus on Screens. Resour. Conserv. Recycl. 2020, 157, 4772. [CrossRef] [PubMed]

45. Palacios Encalada, J.L.; Valero Delgado, A.; Valero Capilla, A.F. Beyond a Tonnage Perspective for the Assessment of Mineral Reources. Focus on Latin America and the Caribbean. 2020. Available online: https://zaguan.unizar.es/record/87141/files/ TESIS-2020-028.pdf (accessed on 25 October 2021).

46. Chancerel, P.; Meskers, C.E.M.; Hagelüken, C.; Rotter, V.S. Assessment of Precious Metal Flows during Preprocessing of Waste Electrical and Electronic Equipment. J. Ind. Ecol. 2009, 13, 791-810. [CrossRef]

47. Kasper, A.C.; Berselli, G.B.T.; Freitas, B.D.; Tenório, J.A.S.; Bernardes, A.M.; Veit, H.M. Printed Wiring Boards for Mobile Phones: Characterization and Recycling of Copper. Waste Manag. 2011, 31, 2536-2545. [CrossRef]

48. Oguchi, M.; Murakami, S.; Sakanakura, H.; Kida, A.; Kameya, T. A Preliminary Categorization of End-of-Life Electrical and Electronic Equipment as Secondary Metal Resources. Waste Manag. 2011, 31, 2150-2160. [CrossRef]

49. Yamane, L.H.; de Moraes, V.T.; Espinosa, D.C.R.; Tenório, J.A.S. Recycling of WEEE: Characterization of Spent Printed Circuit Boards from Mobile Phones and Computers. Waste Manag. 2011, 31, 2553-2558. [CrossRef]

50. Silvas, F.P.C.; Jiménez Correa, M.M.; Caldas, M.P.K.; de Moraes, V.T.; Espinosa, D.C.R.; Tenório, J.A.S. Printed Circuit Board Recycling: Physical Processing and Copper Extraction by Selective Leaching. Waste Manag. 2015, 46, 503-510. [CrossRef] [PubMed]

51. Ueberschaar, M.; Otto, S.J.; Rotter, V.S. Challenges for Critical Raw Material Recovery from WEEE-The Case Study of Gallium. Waste Manag. 2017, 60, 534-545. [CrossRef] [PubMed]

52. Ueberschaar, M.; Dariusch Jalalpoor, D.; Korf, N.; Rotter, V.S. Potentials and Barriers for Tantalum Recovery from Waste Electric and Electronic Equipment. J. Ind. Ecol. 2017, 21, 700-714. [CrossRef]

53. Arshadi, M.; Yaghmaei, S.; Mousavi, S.M. Content Evaluation of Different Waste PCBs to Enhance Basic Metals Recycling. Resour. Conserv. Recycl. 2018, 139, 298-306. [CrossRef]

54. Holgersson, S.; Steenari, B.M.; Björkman, M.; Cullbrand, K. Analysis of the Metal Content of Small-Size Waste Electric and Electronic Equipment (WEEE) Printed Circuit Boards-Part 1: Internet Routers, Mobile Phones and Smartphones. Resour. Conserv. Recycl. 2018, 133, 300-308. [CrossRef]

55. Korf, N.; Løvik, A.N.; Figi, R.; Schreiner, C.; Kuntz, C.; Mählitz, P.M.; Rösslein, M.; Wäger, P.; Rotter, V.S. Multi-Element Chemical Analysis of Printed Circuit Boards—Challenges and Pitfalls. Waste Manag. 2019, 92, 124-136. [CrossRef] [PubMed]

56. Duan, H.; Hou, K.; Li, J.; Zhu, X. Examining the Technology Acceptance for Dismantling of Waste Printed Circuit Boards in Light of Recycling and Environmental Concerns. J. Environ. Manag. 2011, 92, 392-399. [CrossRef] [PubMed]

57. Kaya, M. Recovery of Metals and Nonmetals from Electronic Waste by Physical and Chemical Recycling Processes. Waste Manag. 2016, 57, 64-90. [CrossRef] [PubMed]

58. U.S. Geological Survey Mineral Commodity Summaries 2021. 2021. Available online: https:/ / pubs.er.usgs.gov / publication/ mcs2021 (accessed on 25 October 2021).

59. Wikipedia and U.S. Energy Information Administration (EIA) List of Countries by Electricity Consumption. Available online: https:/ /en.wikipedia.org/wiki/List_of_countries_by_electricity_consumption (accessed on 25 October 2021).

60. Reuter, M.A.; van Schaik, A.; Ballester, M. Limits of the Circular Economy: Fairphone Modular Design Pushing the Limits. World Metal. Erzmetall 2018, 71, 68-79.

61. Valero Navazo, J.M.; Villalba Méndez, G.; Talens Peiró, L. Material Flow Analysis and Energy Requirements of Mobile Phone Material Recovery Processes. Int. J. Life Cycle Assess. 2014, 19, 567-579. [CrossRef] 